\title{
FREEDOM OF EXPRESSION AND INTERNATIONAL CRIMINAL LAW: AN ANALYSIS OF THE DECISION TO CREATE A TESTIMONIAL PRIVILEGE FOR JOURNALISTS
}

\author{
Kelly Buchanan*
}

In a recent decision, the Appeals Chamber of the International Criminal Tribunal for the Former Yugoslavia recognised a qualified privilege for war correspondents in setting out a test that the party requesting its testimony must overcome in order for the Trial Chamber to issue a subpoena. This article examines the decision and the test by comparing it to the approaches of other jurisdictions and any general principles of law that arise therefrom. It also considers whether the decision is consistent with the internationally recognised rights of freedom of expression and to a fair trial. It argues that the international tribunals should take all of these sources of law into account in formulating rules of procedure and evidence, but should also give particular regard to the purposes of international criminal justice, which relate to furthering the establishment of peace.

In this context it is argued that the interests of the international criminal justice system are best served by the creation of a distinct procedural framework that contains clear and principled rules. The Appeals Chamber's formulation of a journalistic privilege not only advances this goal, but also recognises that the ability of war correspondents to report on conflicts is vitally important to the international community, including the international courts themselves. The potential impact on this ability arising from the work of the courts necessitates special consideration and a degree of protection for this group.

\section{INTRODUCTION}

There is no denying that what we see and hear in the media affects both our knowledge and our opinions of world events. Information about conflicts occurring around the world can result in

* Submitted as part of the LLM programme at Victoria University of Wellington (supervisor: Claire Charters). Winner of the Quentin Baxter Prize in Public and International Law for 2003. 
various responses from the international public and action from governments, the United Nations, and non-governmental groups. ${ }^{1}$ One outcome is the indicting of individuals for war crimes. In this context, the ability of journalists to obtain evidence and witness events is often greater than that of government or United Nations officials. ${ }^{2}$ That their newsgathering also means that they may be valuable witnesses in the subsequent trials of alleged war criminals has given rise to considerable debate about what the role of journalists should be in international judicial proceedings. This issue has now reached the chambers of the International Criminal Tribunal for the Former Yugoslavia (ICTY) in what this article will refer to as Randal's case. ${ }^{3}$

Jonathan Randal is a former war correspondent. He spent a period of time covering the conflict in Bosnia as a reporter for the Washington Post. In 1993, Randal published an article in that newspaper in which he quoted Radoslav Brdjanin, who was a housing administrator at the time, as

1 In the case of the conflict in the former Yugoslavia, it is recognised that "as the public was flooded with more and more media reports of atrocities, the pressure on the Security Council increased to confirm those reports and, once confirmed, to take action." Scott T Johnson "On the Road to Disaster: The Rights of the Accused and the International Criminal Tribunal for the Former Yugoslavia" (1998) 10 Intl Legal Persp 111, 114. Furthermore, the United States Government, "faced with mounting political pressure to respond constructively to the continuing reports of widespread atrocities, decided to direct its energies toward establishing an ad hoc international tribunal." Michael P Scharf "Getting Serious About an International Criminal Court" (1994) 6 Pace Intl L Rev 103, 106.

2 For example, Boston Globe foreign editor James Smith points to the situation of journalists covering the allegations of massacres of Palestinian civilians by Israeli troops in the Jenin refugee camp in 2002. While UN inspectors were unsuccessfully seeking access to the site, reporters were "out there testing the implications of a massacre." Quoted in Richard Byrne "Don't Ask, Don't Tell" (30 Sept 2002) Boston Phoenix Boston <http://www.bostonphoenix.com/boston/news_features/top/features/documents/ 02452089.htm> (last accessed 30 September 2003). And in 1997 "journalists who reported from Rwanda and Zaire found themselves in possession of vital information (including plans of imminent attacks) that Tribunal investigators could not have uncovered because they had not received permission to cross into Zaire." Prosecutor v Brdjanin and Talic Case No IT-99-36-T (17 August 2002) "Brief Amici Curiae on Behalf of Various Media Entities and in Support of Jonathan Randal's Appeal of Trial Chamber's 'Decision on Motion to Set Aside Confidential Subpoena to Give Evidence'", para 26.

3 Prosecutor v Brdjanin and Talic Case No IT-99-36-T (7 June 2002, Trial Chamber II) "Decision on Motion to Set Aside Confidential Subpoena to Give Evidence"; Prosecutor v Brdjanin and Talic Case No IT-99-36AR73.9 (11 December 2002, Appeals Chamber) "Decision on Interlocutory Appeal". Although this article predominantly refers to the cases and rules of the ICTY, the discussion applies equally to the International Criminal Tribunal for Rwanda (ICTR), which was created in the same way as the ICTY, with largely the same governing documents and a joint Appeals Chamber. Both Tribunals were established pursuant to Security Council Resolutions passed in accordance with Chapter VII of the United Nations Charter, which authorises the Council to take actions for the maintenance of international peace and security. The International Tribunal for the Prosecution of Persons Responsible for Serious Violations of International Humanitarian Law Committed in the Territory of the Former Yugoslavia Since 1991 (ICTY) was established pursuant to Security Council Resolution 827 (25 May 1993) UN Doc S/Res/827. The International Criminal Tribunal for Rwanda (ICTR) was created pursuant to Security Council Resolution 955 (8 November 1994) UN Doc S/Res/955. 
saying that non-Serbs living in the town of Banja Luka should be "moved out" to create an "ethnically clean space through voluntary movement."4 During the interview, which Randal conducted through the use of an interpreter, Brdjanin also claimed to be preparing laws to expel non-Serbs from government housing to make room for Serb refugees and for Serb combatants' families.

Brdjanin was indicted in 1999 for genocide, war crimes, crimes against humanity, and grave breaches of the Geneva Conventions of 1949.5 The prosecutor sought to introduce Randal's article into evidence as pertaining to the state of mind of the accused leading up to the events for which he was indicted. The defence challenged this move on the basis that the introduction of the article without the opportunity for cross-examination of the writer was unfair, particularly as the accused considered the interpreter to be hostile to him and may have misrepresented what he said. ${ }^{6}$ The prosecutor therefore obtained a subpoena to compel Randal to testify both to the accuracy of the quotes and the demeanour of the accused during the interview. ${ }^{7}$ Randal refused to comply and challenged the subpoena, arguing that the Tribunal should recognise a qualified testimonial privilege for journalists in light of their important, and often dangerous, role of reporting from conflict zones, and the effect that compelled testimony would have on the right to freedom of expression.

This article examines the decision of the Appeals Chamber of the International Criminal Tribunal for the Former Yugoslavia (Appeals Chamber) to establish a test that restricts the ability of the Tribunal to subpoena war correspondents. It seeks to answer the following questions: Did the Tribunal have the authority to create a qualified privilege for journalists? If so, what sources of law should be considered and applied in formulating the rule? And, finally, does the Appeals Chamber test balance the competing interests of journalists, the international community, and the Tribunal in a way that is conducive to meeting the needs of the international criminal justice system? A related question is the extent to which the international tribunals may consider their own special circumstances in formulating rules of procedure and evidence. That the work of the tribunals, and of

4 Jonathan Randal "Preserving the Fruits of Ethnic Cleansing: Bosnian Serbs, Expulsion Victims See Process as Beyond Reversal" (11 February 1993) The Washington Post Washington DC A34. Brdjanin was later appointed acting Vice-President in the Government of Republika Srpska.

5 Prosecutor $v$ Brdjanin and Talic Case No IT-99-36-PT (14 March 1999) "Initial Indictment". The indictment alleged that Brdjanin "played a leading role in the establishment of structures for the take-over of power in the Banja Luka region by the Bosnian Serb authorities." He is said to have participated in the implementation of policies of forced deportation and systematic liquidation of Bosnian Muslim and Croatian peoples in the area. Although the indictment has been amended, these allegations are the essence of the case against Brdjanin. See Prosecutor v Radoslav Brdjanin (7 October 2002) "Fifth Amended Indictment."

6 Prosecutor v Brdjanin and Talic Case No IT-99-36-T (7 June 2002, Trial Chamber II) "Decision on Motion to Set Aside Confidential Subpoena to Give Evidence", para 3.

7 See Prosecutor v Brdjanin and Talic, above n 6, para 2. 
war correspondents, has special characteristics that justify a distinct approach to journalistic privilege appears to underlie the reasoning of the Appeals Chamber.

A core proposition of this article is that a clear and principled system of procedural rules must be developed through the work of the international criminal tribunals, and the decision in Randal's case is one that advances this goal. The Appeals Chamber test for overcoming the journalistic privilege finds its grounding in the underlying rationale for journalists' public interest privilege in domestic settings, but also takes into account the special context and purposes of international criminal justice, and the need to keep abreast of developments concerning fundamental human rights. These considerations are vitally important to ensuring the long-term legitimacy, and subsequent effectiveness, of the international criminal justice system. Furthermore, the provision of some protection for journalists in a way that fairly balances the competing interests of the right to freedom of expression and the administration of justice serves the broad needs of the international community to receive information about acts committed during conflicts, and to respond accordingly.

\section{RANDAL'S CASE: ARGUMENTS AND DECISIONS}

As a result of the defence's challenge to the admission of his article Randal was subpoenaed pursuant to Rule 54 of the ICTY's Rules of Procedure and Evidence (Rules). ${ }^{8}$ This provision authorises the Trial Chamber to "issue such orders, summonses, subpoenas, warrants and transfer orders as may be necessary for the purposes of an investigation or for the preparation or conduct of the trial."9

\section{A The Arguments of the Parties ${ }^{10}$}

In challenging the subpoena, Randal argued that the consequences of routinely compelling the testimony of journalists would be that: ${ }^{11}$

(i) journalists' independence would be undermined and journalists would have fewer opportunities to conduct interviews with officials with superior authority, particularly in conflicts that are ongoing, (ii) journalists would as a collective profession be put at risk of greater harm and danger, including exposing

8 Rules of Procedure and Evidence, International Tribunal for the Prosecution of Persons Responsible for Serious Violations of International Humanitarian Law Committed in the Territory of Former Yugoslavia Since 1991 (11 February 1994) UN Doc IT/32 (as amended) ["Rules of Procedure and Evidence"].

9 Rules of Procedure and Evidence, above n 8, Rule 54. Rule 77 provides that the tribunal may hold people in contempt, and consequently fine or imprison them, for failing to comply with an order to appear before it.

10 The Defence did not provide a reply, despite earlier indicating that they would like to participate in the discussion before the Tribunal. See Prosecutor $v$ Brdjanin and Talic Case No IT-99-36-AR73.9 (11 December 2002, Appeals Chamber) "Decision on Interlocutory Appeal", footnote 10.

11 Prosecutor v Brdjanin and Talic, above n 6, para 11. 
their sources to such risk and, as a result therefore, (iii) the amount of information that conflict zone reporters are able to produce, including specifically information about crimes against humanity, would tend to dry up.

Randal considered that the Tribunal's power to subpoena witnesses is not absolute, and should be limited by "public policy concerns", ${ }^{2}$ in this case, the international community's interest in receiving information from war correspondents. He therefore argued for a multi-part test that would essentially create a "presumption against compulsory process for journalists except in extraordinary situations."13

On the other hand, the prosecution argued that testifying created no danger "that publicly important information will become unavailable,"14 and therefore that Randal offered "no substantial interest that would override the powerful public interest that all relevant evidence be available to [the] Tribunal, and Brdjanin's right to a fair trial."15 It submitted that the risk of harm or loss of sources for journalists arises not from the possibility that they might be called to testify about the stories that they publish, but from the fact of publication in itself. ${ }^{16}$

\section{B The Trial Chamber Decision}

The Trial Chamber II, while accepting that journalists reporting from conflict areas "play a vital role in bringing to the attention of the international community the horrors and reality of the conflict," and should therefore not be subpoenaed unnecessarily, ${ }^{17}$ rejected Randal's claim to privilege. The judgment does indicate, however, that in a different case involving the disclosure of confidential sources, the Tribunal would not provide a lower level of protection than that set out in the decision of the European Court of Human Rights in the case of Goodwin v United Kingdom. ${ }^{18}$ It therefore held that since this question did not arise in Randal's situation this was the wrong case to

12 Prosecutor $v$ Brdjanin and Talic, above n 6, para 9.

13 Prosecutor $v$ Brdjanin and Talic, above n 6, paras 12 and 14. The test proposed by Randal was that the Trial Chamber must be satisfied that the journalist's testimony would provide admissible evidence that "(1) is of 'crucial importance' to determining a defendant's guilt or innocence; (2) cannot be obtained 'by any other means or from any other witness'; (3) will not require the journalist to breach any obligation of confidence; (4) will not place the journalist, his family, or his sources in reasonably apprehended personal danger; and (5) will not serve as a precedent that will 'unnecessarily jeopardise the effectiveness or safety of other journalists reporting from that conflict zone in the future."' Prosecutor v Brdjanin and Talic Case No IT-9936-AR73.9 (11 December 2002, Appeals Chamber) "Decision on Interlocutory Appeal", para 15.

14 Prosecutor $v$ Brdjanin and Talic, above n 6, para 16.

15 Prosecutor v Brdjanin and Talic, above n 6, para 22.

16 Prosecutor $v$ Brdjanin and Talic, above n 6 para 25.

17 Prosecutor v Brdjanin and Talic, above n 6, para 25.

18 Goodwin v United Kingdom (1996) 22 EHRR 123. See Part IV 32 United Kingdom/Europe. 
set out a new privilege. ${ }^{19}$ Thus it was sufficient that his testimony would be 'pertinent' to the case in order to uphold the subpoena. ${ }^{20}$

The Trial Chamber decision therefore suggests that where aspects of the right to freedom of expression are implicated, particularly in cases involving the protection of confidential sources, this will "inevitably need to be considered within the overriding principle that the course of justice is not unduly impeded by the withholding of evidence."21 The approach that it proposed in such situations is a "delicate balancing exercise which will vary from case to case."22

\section{The Amicus Curiae and the Appeals Chamber Decision}

Randal's appeal of the Trial Chamber decision was supported by an amicus brief filed on behalf of 34 media organisations from around the world. ${ }^{23}$ The case, and the decision of other journalists to testify voluntarily at the Tribunals, ${ }^{24}$ had generated considerable discussion among journalists and media commentators. ${ }^{25}$ The amici asked the Appeals Chamber to use the opportunity provided by Randal's case to set out a clear test with regard to "safeguarding journalists' rights."26

19 Prosecutor v Brdjanin and Talic, above n 6, paras 28 and 31. The article explicitly identified Brdjanin as being the source of the quotes.

20 Prosecutor v Brdjanin and Talic, above n 6, para 32.

21 Prosecutor v Brdjanin and Talic, above n 6, para 27.

22 Prosecutor $v$ Brdjanin and Talic, above n 6, para 27.

23 Prosecutor v Brdjanin and Talic Case No IT-99-36-T (17 August 2002) "Brief Amici Curiae on Behalf of Various Media Entities and in Support of Jonathan Randal's Appeal of Trial Chamber's 'Decision on Motion to Set Aside Confidential Subpoena to Give Evidence"'. This was thought to be the largest group of media organisations ever to join a brief of this type. Leave was granted to the amici to submit the brief under Rule 74 of the Rules of Procedure and Evidence which states: "A Chamber may, if it considers it desirable for the proper determination of a case, invite or grant leave to a State, organisation or person to appear before it and make submissions on any issue specified by the Chamber."

24 In particular, Ed Vulliamy of The Guardian testified in the trial of Tihomir Blaskic. See Prosecutor $v$ Blaskic Case No IT-95-14 (3 March 2000, Trial Chamber I) "Judgment". More recently, BBC correspondent Jackie Rowland testified against Slobodan Milosevic. See Prosecutor v Milosevic Case No IT-02-43 (27-28 August 2002, Trial Chamber) Unofficial Transcript, 8912-9012. See also Stephanie van den Berg "British Journalist Gives Evidence at Milosevic Trial" (27 August 2002) <http://www.softcom.net/ webnews/wed/cx/Qwarcrimes-yugo-media.Rz1y_CaR.html> (last accessed 19 September 2003); Ed Vulliamy "An Obligation to the Truth" (19 May 2002) The Observer London <http://www.observer.co.uk/ milosevic/story/0,10639,718225,00.html> (last accessed 19 September 2003). The two journalists considered that they had a duty to testify, both in terms of their accountability to their readers and to the cause of international justice.

25 See, for example, Chantal Eustace "Journalists on the scales of justice" (October 2002) 5 Thunderbird 1 <http://www.journalism.ubc.ca/thunderbird/2001 02/october02/tribunal.html> (last accessed 19 September 2003); Ariel Meyerstein "The Role of War Correspondents in International Criminal Justice: ICTY orders Journalist to Testify" (19 June 2002) <http://www.crimesofwar.org/onnews/news-warcorrespond.html > (last accessed 19 September 2003); Elaine Hargrove-Simon "Former Washington Post Reporter Subpoenaed by 
In its decision, the Appeals Chamber emphasised that they were concerned with a particular group of journalists only, namely "war correspondents".27 It considered that "society's interest in protecting the integrity of the newsgathering process is particularly clear and weighty" in the case of this group. ${ }^{28}$ In particular, this is due to the importance of their ability to awaken the international community to human rights abuses, which in turn has the potential to assist with bringing perpetrators to justice. ${ }^{29}$ Therefore, being satisfied that there was a public interest in the work of war correspondents, and that compelling them to testify would have an impact on their ability to carry out this work, ${ }^{30}$ the Appeals Chamber asked "what test is appropriate to balance the public interest in accommodating the work of war correspondents with the public interest in having all relevant evidence available to the court and, where it is implicated, the right of the defendant to challenge the evidence against him?"31

International Criminal Tribunal" (2002) 7 Silha Bulletin no 4 <http://silha.cla.umn.edu/summer2002.htm> (last accessed 25 August 2003); Roy Gutman "Consequences Occur When Reporters Testify" (2003) Nieman Reports 74 <http://www.nieman.harvard.edu/reports/03-1NRspring/74-77V57N1.pdf> (last accessed 29 September 2003); William Safire "International Court Will Inhibit Press Freedom" (June 21 2002) The New York Times New York <http://www.theage.com.au/articles/2002/06/20/ 1023864477172.html> (last accessed 15 August 2003); Brandt Goldstein "When Can You Make a Reporter Testify?" (25 June 2002) <http://slate.msn.com/?id=2067357> (last accessed 15 August 2003). In particular, the responses highlighted the divergence in opinions between United States journalists and their European counterparts. As one law professor commented, while "American journalists tend to see the tribunal's subpoena as a threat to First Amendment freedoms, many European journalists see testimony before the tribunal as an extension of the journalistic enterprise." Dianne F Orentlicher, quoted in Nina Bernstein "Can War Reporters be Witnesses, Too?" (14 December 2002) The New York Times New York $<$ http://loper.org/ george/trends/2002/Dec/75.html> (last accessed 19 September 2003).

26 Prosecutor v Brdjanin and Talic, above n 23, para 20.

27 Prosecutor v Brdjanin and Talic Case No IT-99-36-AR73.9 (11 December 2002, Appeals Chamber) "Decision on Interlocutory Appeal", para 29. The Appeals Chamber defined war correspondents as being "individuals who, for any period of time, report (or investigate for the purposes of reporting) from a conflict zone on issues relating to the conflict." Although there may arise issues regarding who qualifies as a war correspondent for the purposes of this definition, and indeed there is considerable debate about the meaning of 'journalist' in domestic settings, such a discussion is beyond the scope of this paper. For general discussion regarding the definition of 'journalist' in terms of testimonial privileges see Clay Calvert "And You Call Yourself a Journalist?: Wrestling with the Definition of 'Journalist' in the Law" (1999) 103 Dic L Rev 411; Laurence B Alexander "Looking Out for the Watchdogs: A Legislative Proposal Limiting the Newsgathering Privilege to Journalists in the Greatest Need of Protection for Sources and Information" (2002) 20 Yale L and Poly Rev 97.

28 Prosecutor v Brdjanin and Talic, above n 27, para 36.

29 Prosecutor $v$ Brdjanin and Talic, above n 27, para 36 (stating that "[t]he information uncovered by war correspondents has on more than one occasion provided important leads for the investigators of this Tribunal").

30 Prosecutor v Brdjanin and Talic, above n 27, para 44. See Part V C 3 The impact of compelling testimony.

31 Prosecutor v Brdjanin and Talic, above n 27, para 34. 
The test that was formulated was largely a watered-down version of that proposed by the amicus brief, ${ }^{32}$ and places the burden on the subpoenaing party to show firstly that the evidence sought from a war correspondent "is of direct and important value in determining a core issue in the case," and secondly that the information cannot "reasonably be obtained elsewhere."33

The judges indicated that they found it difficult to see how Randal's testimony could satisfy the first limb of the test due to his inability to speak Serbo-Croatian and therefore to confirm what had been said during the interview. ${ }^{34}$ As a result, the subpoena was overturned.

\section{Application of the Appeals Chamber Test}

On 29 January 2003, the Prosecution filed a motion for a second subpoena of Randal. This provided the first opportunity for the application of the Appeals Chamber test. ${ }^{35}$

The indication from the Appeals Chamber that it had difficulty seeing how Randal's testimony could satisfy the first limb proved influential. ${ }^{36}$ Despite finding that the proposed testimony went to a core issue of the case, ${ }^{37}$ the Trial Chamber held that Randal's inability to speak Serbo-Croatian meant that not only could he not confirm the accuracy of the quotes, but he also could not reliably comment on the demeanour of the accused during the interview, since this required an understanding of what was actually being said. ${ }^{38}$ Thus the testimony could not be of 'direct and important value' to the issue of the accused's intent and Randal could not be required to testify. ${ }^{39}$

32 Prosecutor v Brdjanin and Talic, above n 23, para 43. This test would require a showing that a journalist's testimony "(1) is absolutely essential to the case; and (2) the information cannot be obtained by any other means." Where 'essential' is defined as requiring that the contribution of the testimony must "be critical to determining the guilt or innocence of a defendant."

33 Prosecutor $v$ Brdjanin and Talic, above $\mathrm{n}$ 27, para 50. War correspondents are not prevented from testifying voluntarily by this decision.

34 Prosecutor v Brdjanin and Talic, above n 27, para 54.

35 Prosecutor v Brdjanin Case No IT-99-36-T (30 June 2003, Trial Chamber II) "Decision on Prosecution's Second Request for a Subpoena of Jonathan Randal".

36 Prosecutor v Brdjanin and Talic, above $\mathrm{n}$ 35, para 29 (stating that it was "difficult to depart from the reasoning of the majority of the Appeals Chamber without having to anticipate an evaluation of evidence and facts which cannot be done at this particular stage or proceedings").

37 Prosecutor $v$ Brdjanin and Talic, above $\mathrm{n}$ 35, para 17 (this was because, "if accepted as true, the statements attributed to the accused in his article go to the accused's criminal responsibility, particularly his intent").

38 Prosecutor v Brdjanin and Talic, above n 35, para 33.

39 Prosecutor v Brdjanin and Talic, above n 35, para 40. The Trial Chamber considered it unnecessary to resolve whether the evidence sought satisfied the second limb of the test. If it had, it may have come to the conclusion that although the interpreter was also a journalist there was no alternative source for the information sought apart from him, and therefore the requirements of this limb would also not be met in the case of Randal. Based on the findings of the Trial Chamber, it would also seem that the subpoena of the 


\section{FORMULATING RULES OF PROCEDURE AND EVIDENCE}

The ad hoc tribunals for the former Yugoslavia and for Rwanda (ICTR) are required to apply the customary international law in existence at the time that the offences within their jurisdictions were committed. ${ }^{40}$ However, it was left to the tribunals to formulate their own rules of procedure and evidence. ${ }^{41}$ An important and ongoing feature of their work is therefore the development of a distinct procedural system in the realm of international criminal law. The tribunals' approach to resolving procedural issues is crucial to ensuring the legitimacy and viability of the international criminal justice system. This is because the ad hoc tribunals, and the newly created International Criminal Court (ICC), depend on the support and co-operation of states in order to exist. ${ }^{42}$ This cannot be enhanced, or in fact maintained, unless procedures are viewed as fair and principled.

\section{A The Ability to Formulate Rules and the Applicable Sources of Law}

The governing statutes of the international tribunals contain no evidentiary rules. ${ }^{43}$ Instead, Article 15 of the ICTY Statute grants the judges the authority to "adopt rules of procedure and evidence for the conduct of the pre-trial phase of the proceedings, trials and appeals, the admission of evidence, the protection of victims and witnesses and other appropriate matters." ${ }^{44}$ This saw the creation of a relatively skeletal series of rules, which were set out in the Rules of Procedure and Evidence.

interpreter would satisfy the first limb of the Appeals Chamber test due to their ability to directly confirm what was said in the interview. The decisions give no indication of the reasons for the interpreter not being subpoenaed instead of Randal.

40 "Report of the Secretary General Pursuant to Paragraph 2 of Security Council Resolution 808 (1993)" (3 May 1993) UN Doc S/25704, para 29 ["Report of the Secretary General"]. An important principle is therefore that of nullum crimen sine lege (no crime without law). See Report of the Secretary General, para 34.

41 Report of the Secretary General, above n 40, para 83. Evidentiary privileges are a matter of procedure and evidence because they concern witness testimony. See Natasha A Affolder "Tadic, the Anonymous Witness and the Sources of International Procedural Law" (1998) 19 Mich J Intl L 445, 473.

42 See Jacob Katz Cogan "International Criminal Courts and Fair Trials: Difficulties and Prospects" (2002) Yale J Intl L 111, 119 (stating that "international criminal courts are dependent on other organisations states, most importantly - to give them things. These things - money, evidence, access to evidence, defendants, witnesses, witness protection, court personnel, prison facilities, and the enforcement of orders and judgments - are all necessary for the courts' success, and, indeed, without them, the courts could not operate or exist").

43 Statute of the International Criminal Tribunal for the Former Yugoslavia (as amended), adopted by and annexed to Security Council Resolution 827 (25 May 1993) UN Doc S/Res/827 ["ICTY Statute"]; Statute of the International Criminal Tribunal for Rwanda, annexed to Security Council Resolution 955 (8 November 1994) UN Doc S/Res/955 ["ICTR Statute"].

44 ICTY Statute, above n 43, art 15. Article 14 of the ICTR Statute expressly adopts the rules of the ICTY for the purposes of the proceedings in the ICTR. 
After the Rules were drafted, however, the issue of interpretation arose with regard to their application in particular situations. Apart from applying their wording and purpose, the Tribunals must ensure that the Rules are interpreted in a manner that is "consistent with the Statute as the constituent instrument of the International Tribunal and as the exclusive basis for its competence and authority." 45

The generality of the Rules indicates that they were not intended to be comprehensive and can be seen to "deliberately invite an expansive interpretation to fill in the missing spaces." 46 That there is a gap in the Rules with regard to journalists' privilege was recognised by the Appeals Chamber in Randal's case in stating that "[n]either the Statute nor the relevant rules offer much guidance on the issue being considered here." ${ }^{47}$ Amendments to the Rules are permissible, ${ }^{48}$ and this has occurred on a number of occasions, ${ }^{49}$ but the Tribunals have often filled the gaps in direct response to the particular issues that arise in the cases before them..$^{50}$ The authority for this practice in the context of the rules of evidence is provided by Rule 89(B), which states that "in cases not otherwise provided for in this Section, a Chamber shall apply rules of evidence that will best favour a fair determination of the matter before it and are consonant with the spirit of the Statute and the general principles of law."51

45 Natasha A Affolder "Tadic, the Anonymous Witness and the Sources of International Procedural Law" (1998) 19 Mich J Intl L 445, 467. See also Richard May and Marieke Wierda "Trends in International Criminal Evidence: Nuremberg, Tokyo, The Hague, and Arusha" (1999) Col J Transnatl L 725, 736; Prosecutor v Erdemovic Case No IT-96-22-A (7 October 1997, Appeals Chamber) "Separate and dissenting opinion of Judge Cassesse," para 2; Prosecutor v Kordic Case No IT-95-14/2 (18 September 2000, Appeals Chamber) "Decision on Appeal regarding the Admission into Evidence of Seven Affidavits and one Formal Statements" para 23.

46 Rod Dixon "Developing International Rules of Evidence for the Yugoslav and Rwanda Tribunals" (1997) Transnatl L and Contemp Prob 81, 95.

47 Prosecutor $v$ Brdjanin and Talic, above n 27, para 31.

48 Rules of Procedure and Evidence, above n 8, Rule 6 provides "(A) Proposals for amendment of the Rules may be made by a Judge, the Prosecutor or the Registrar and shall be adopted if agreed to by not less than ten permanent Judges at a plenary meeting of the Tribunal convened with notice of the proposal addressed to all Judges. (B) An amendment to the Rules may be otherwise adopted, provided it is unanimously approved by the permanent Judges."

49 In fact, this has occurred 27 times since the Rules of Procedure and Evidence were adopted in 1994.

50 Dixon, above n 46, 82.

51 Rules of Procedure and Evidence, above n 8, Rule 89(B). 
The merit of the Tribunals being able to supplement the Rules through their decisions has been considered by a number of commentators. ${ }^{52}$ One position is that this allows for the creation of a distinct and workable system in the context of international justice: ${ }^{53}$

[L]awyers with trial experience will be left with a sense of frustration from the rules. They will find many lacunae, especially in the provisions relating to evidence. ... Fortunately, Rule 89(B), which allows the trial chambers to apply rules of evidence that will best favour a fair determination of the issues, offers to the Tribunal and the lawyers who appear before it a golden opportunity to craft a workable and just procedural and evidentiary regime that will foster the interests of international justice.

Admittedly, this will require imagination, open-mindedness, and patience.

The approach that should be taken in creating such a regime, however, is unclear. In particular, there is uncertainty regarding the external sources that the Tribunals should consider in formulating rules and the weight that should be accorded to these. The Statutes and Rules of the Tribunals contain no applicable law provision. ${ }^{54}$

Although the Tribunals are not bound to apply national rules of evidence, ${ }^{55}$ Rule 89(B) advocates the consideration of general principles of law as derived from domestic systems. ${ }^{56}$ Such principles may be defined as "some proposition of law so fundamental that it will be found in

52 See Joseph L Falvey Jr "United Nations Justice or Military Justice: Which is the Oxymoron? An Analysis of the Rules of Procedure and Evidence of the International Tribunal for the Former Yugoslavia" (1995) Fordham Intl L J 475, 518 (arguing that extensive rules, such as those governing the evidentiary process in military tribunals, are "unnecessary before a body such as the Tribunal and would only complicate the process."); Mercedeh Momeni "Balancing the Procedural Rights of the Accused Against a Mandate to Protect Victims and Witnesses: An Examination of the Anonymity Rules of the International Criminal Tribunal for the Former Yugoslavia" (1997) 41 How L J 155, 159 (stating that "it can be inferred that the Secretary General intended to establish a framework within which the Tribunal could operate effectively, while allowing the drafters of the Rules some licence to create the procedures for applying international humanitarian law that are acceptable to the international community.") Contrast Thomas Buergenthal, quoted in Dixon, above n 46, 91 (arguing that the practice of developing rules ad hoc "tends to create a great deal of unnecessary confusion and probably also some unfairness, especially for those litigants who are represented by inexperienced counsel.").

53 Daniel D Ntanda Nsereko "Rules of Procedure and Evidence of the International Tribunal for the Former Yugoslavia" (1994) 5 Crim L R 507, 554.

54 This is in contrast to the Statute of the International Court of Justice (26 June 1945) 59 Stat 1031, in which art 38(1) provides that the law to be applied in the Court shall be international conventions, international custom, general principles of law and, as a subsidiary means, judicial decisions and teachings.

55 Rules of Procedure and Evidence, above n 8, Rule 89(A) provides: "A Chamber shall apply the rules of evidence set forth in this Section, and shall not be bound by national rules of evidence."

56 The legislative history of Rule 89(B) reveals that "other sources were explicitly rejected in favour of general principles." Natasha A Affolder, above n 45, 483. 
virtually every legal system",57 and their gap-filling function has been consistently recognised by courts operating in the international sphere. ${ }^{58}$

The Tribunals are also arguably restrained in their rulemaking by customary international law, 59 and certainly by the need to have regard to the rights of the accused and the protection of victims and witnesses. ${ }^{60}$ In considering these elements, and the procedural rules of other jurisdictions, the Chambers have emphasised the special circumstances within which they operate. These include the distinct legal and factual nature of the crimes that are being prosecuted, ${ }^{61}$ the fact that there is no permanent police force or witness protection programme to support the work of the Tribunal, ${ }^{62}$ and that there has been a lack of cooperation from states in this context. ${ }^{63}$ Another characteristic unique to the Tribunals is the utilisation of both common and civil law aspects, which requires "innovative" approaches to rulemaking. ${ }^{64}$

57 Mark W Janis An Introduction to International Law (3d ed, Aspen, New York 1993) 55.

58 See generally Antonio Cassesse International Law (Oxford, 2001) 158; Malcolm N Shaw International Law (4th ed, Cambridge, 1997) 77-78.

59 See Prosecutor v Simic Case No IT-95-9 (27 July 1999, Trial Chamber) "Ex Parte Confidential Decision on the Prosecution Motion under Rule 73 for a Ruling Concerning the Testimony of a Witness", para 42 (stating that "the International Tribunal's Rules may be affected by customary international law," even where this is not expressly provided for in the Rules). Customary international law is generally defined as those principles which are evident in the practice of states, and which are widely accepted as being binding in law (otherwise known as "opinio juris"). See generally D J Harris Cases and Materials on International Law (5 ${ }^{\text {th }}$ ed, Sweet \& Maxwell, London, 1998) 23-45.

60 Article 20(1) of the ICTY Statute requires the Trial Chamber to "ensure that a trial is fair and expeditious and that proceedings are conducted in accordance with the rules of procedure and evidence, with full respect for the rights of the accused and due regard for the protection of victims and witnesses." Article 21 then sets out the fair trial rights of the accused, which are 'subject to' the provision in Article 22 for the protection of victims and witnesses.

61 See Dixon, above n 46, 87 (stating that the crimes are of a "scale and severity...never encountered in national prosecutions."); Patricia M Wald "To 'Establish Incredible Events by Credible Evidence': The Use of Affidavit Testimony in Yugoslavia War Crimes Tribunal Proceedings" (2001) 42 Harv Intl L J 535, 536 (considering that prosecuting war crimes presents "unique problems" due to the elements that need to be proven). See ICTY Statute, above n 43, arts 2-5 for the elements of the crimes. That the conflict in Yugoslavia was ongoing during the ICTY's deliberations is also a factor that has been raised in the decisions of the Chambers. See Prosecutor v Tadic Case No IT-94-1 (10 August 1995, Trial Chamber) "Decision on the Prosecutor's Motion Requesting Protective Measures for Victims and Witnesses", para 42.

62 Prosecutor v Tadic, above n 61, para 42. See also Prosecutor v Brdjanin and Talic, above n 27, para 16 Judge Shahabuddeen (noting that "a domestic court is aided by the full apparatus of detection and enforcement by the state. By contrast, the Tribunal is not.").

63 See Sara Stapleton "Ensuring a Fair Trial in the International Criminal Court: Statutory Interpretation and the Impermissibility of Derogation" (1999) 31 NYU J Intl L and Poly 535, 542.

64 See Prosecutor v Tadic, above n 61, para 22. 
It is therefore apparent that the Tribunals have sought to interpret their guiding documents with regard to its own context and "unique legal framework"65 in order to "mould its Rules and procedures to fit the task at hand." 66 This can be seen as utilising an approach to interpretation, often applied in interpreting human rights instruments, that permits consideration of the meaning of documents with regard to what would be most suitable on policy grounds. ${ }^{67}$

The lack of specific guidance in the Rules with regard to evidentiary privileges therefore does not mean that the tribunals lack authority to recognise any. Such a decision restricts the ability of the chambers to hear otherwise admissible testimony. In any court the admission of evidence is a key factor in determining the truth. The following section sets out the unique approach of the international tribunals as this creates the particular climate for the recognition of a journalistic privilege.

\section{B The Admission of Evidence in the International Tribunals}

The Tribunals' Rules essentially "represent a hybrid of Anglo-American adversarial trial practice and civil-continental procedures." 68 That is, the presentation of evidence generally follows the adversarial model that is predominant in common law justice systems, with each party presenting their case and having the opportunity to cross-examine witnesses and discredit the evidence of their opposition. 69

The impact of civil law philosophy is more clearly evident in the rules regarding the admission of evidence. ${ }^{70}$ Under inquisitorial systems, rules governing admissibility leave wide discretion for

65 Prosecutor $v$ Tadic, above n 61, para 30.

66 Prosecutor v Tadic, above n 61, para 23.

67 Dixon, above n 46, 101-102.

68 Wald, above n 61, 537. See also May and Wierda, above n 45, 735.

69 May and Wierda, above n 45, 735 and 739. In particular, Rule 85 of the Rules of Procedure and Evidence reflects the dominance of the common law approach in this context. See also Rule 84 ("Opening Statements"), Rule 86 ("Closing Arguments"). The common law background of these rules is recognised in Prosecutor v Delalic Case No IT-96-21 (19 August 1998, Trial Chamber) "Decision on the Motion on Presentation of Evidence by the Accused."

70 Gregory A McClelland "A Non-Adversary Approach To International Criminal Tribunals" (2002) 26 Suffolk Transnatl L Rev 1, 19. Other features of the civil law system are evident in the approach of the Tribunals, for example in the fact that the trials are before a three-judge bench, as opposed to the jury trials of common law systems, and "in the defendant's right to give an unsworn and uncross-examined statement at the beginning of the trial, as well as to take the stand as an ordinary witness; in the prosecutor's right to appeal an acquittal; and in greater leeway for judges questioning at trial or calling their own witnesses." Wald, above n 61, 537. 
judges, with relevancy and best evidence standards being the main test. ${ }^{71}$ This is reflected in Rule 89(C), which allows a Trial Chamber to "admit any relevant evidence that it deems to have probative value."72 It is argued that such a liberal approach is necessary "for the full presentation of all the surrounding circumstances."73 Another rationale for granting the judges such discretion is that they are professional jurists who are "capable of according appropriate weight to evidence of varying reliability."74 Thus the judges will determine the weighting to be accorded to evidence by considering its probative value. ${ }^{75}$ Rule 89 (D) requires the judges to consider the rights of the accused in providing that "[a] Chamber may exclude evidence if its probative value is substantially outweighed by the need to ensure a fair trial."76

In a demonstration of the lenient admission standards of the tribunals, the Trial Chamber had earlier found Randal's article and his proposed testimony to be prima facie admissible. ${ }^{77}$ This was despite the evidence being essentially hearsay. ${ }^{78}$ Furthermore, in its application of the Appeals Chamber test, the Trial Chamber found that the word 'direct' in the first limb does not necessarily rule out the possibility that journalists' hearsay evidence may satisfy the test. ${ }^{79}$ The impact of the Appeals Chamber test, however, can generally be seen as increasing the threshold for the subpoenaing of war correspondents from being that of simple admissibility of their evidence to requiring a higher showing of its importance. ${ }^{80}$

71 McClelland, above n 70, 19; See also May and Wierda, above n 45, 727. In contrast, common law systems often have a number of opportunities for excluding evidence.

72 Rules of Procedure and Evidence, above n 8, Rule 89(C).

73 May and Wierda, above n 45, 732.

74 McClelland, above n 70, 30. See Prosecutor v Tadic Case No IT-94-1 (5 August 1996) "Decision on Defence Motion on Hearsay", 30.

75 In particular, the requirement of reliability has been found to be implicit in the definition of 'probative value.' See Prosecutor v Delalic Case No IT-96-21-T, (19 January 1998, Trial Chamber) "Decision on Motion of Prosecution for Admissibility of Evidence", para 20; Prosecutor v Aleksovski Case No IT-9514/1 (16 February 1999, Appeals Chamber) "Decision on Prosecutor's Appeal on Admissibility of Evidence", para 15.

76 Rules of Procedure and Evidence, above n 8, Rule 89(D).

77 Prosecutor v Brdjanin and Talic, above n 6, para 5.

78 Out of court statements such as hearsay evidence are generally inadmissible in common law systems due to the court being unable to adequately test their content.

79 Prosecutor v Brdjanin, above n 35, para 21. Instead "direct" was seen as equating with "to the point".

80 See Prosecutor v Brdjanin and Talic, above n 27, paras 35-36 Judge Shahabuddeen. The approach of the Appeals Chamber suggests that a Trial Chamber will first need to consider the admissibility of the war correspondent's evidence in terms of Rule 89(C), and then, if it finds in favour of this, to consider whether it also satisfies the Appeals Chamber test so as to overcome the privilege and allow the issuance of a subpoena. See Prosecutor v Brdjanin and Talic, above n 27, para 32. The same process was not applied to 


\section{THE LAW OF PRIVILEGE}

\section{A The Traditional Law of Privilege}

Evidentiary, or testimonial, privileges allow for the non-disclosure of certain types of information, and therefore for persons to refuse to answer questions in a court of law. Although such rules are controversial because they are "counter-intuitive in a system designed to arrive at the truth," various privileges have developed over time as a means of "protecting interests and relationships considered sufficiently important to society to warrant the loss of otherwise competent testimony or material evidence." ${ }^{81}$ John Henry Wigmore, in his respected and influential treatise on evidence, argued that a new evidentiary privilege should meet the following criteria: ${ }^{82}$

(1) The communication must originate in confidence that it will not be disclosed.

(2) This element of confidentiality must be essential to the full and satisfactory maintenance of the relation between the parties.

(3) The relation must be one which in the opinion of the community ought to be sedulously fostered.

(4) The injury that would inure to the relation by the disclosure of the communication must be greater than the benefit thereby gained by the correct disposal of litigation.

A qualified, as opposed to an absolute, privilege therefore allows a litigant to overcome the presumption of a privilege by proving an overriding need or interest in the information that outweighs the interest in preventing disclosure.

In Randal's case, the public interest asserted was that arising from the ability of war correspondents to obtain and impart information of concern to the international community. The formulation of a privilege in this case is not the only privilege that has been recognised by the international tribunals.

Randal's article itself, however, which was deemed to admissible even in the absence of Randal's testimony, with the weighting accorded to it to be determined in the final judgment of the court. See Prosecutor $v$ Brdjanin, above n 35, paras 41-42. See also Part V E The Residual Admission of Evidence.

81 Anthony L Fargo "The Journalist's Privilege for Non-Confidential Information in States with Shield Laws" (1999) 4 Comm L and Poly 325, 361. See also Karl H Schmid "Journalist's Privilege in Criminal Proceedings: An Analysis of United States Courts of Appeals' Decisions from 1973 to 1999" (2002) 39 Am Crim L Rev 1441, 1448; Stephen Bates "The Reporter's Privilege, Then and Now" (Research Paper R-23, Harvard University, 2000) 3 <http://www.ksg.harvard.edu/presspol/publications/pdfs/100831\%20R-23.pdf> (last accessed 29 September 2003).

82 John Henry Wigmore Evidence in Trials at Common Law (McNaughton rev ed, Little Brown \& Co, Boston, 1961) vol 8, § 2285, 527. 


\section{B Other Evidentiary Privileges in the International Tribunals}

The Statutes and Rules of the tribunals set out two privileges that have long been recognised in common law jurisdictions. The traditional lawyer-client privilege applies by virtue of Rule 97, ${ }^{83}$ and the privilege against self-incrimination is set out as a basic fair trial right in Article 21 of the ICTY Statute. ${ }^{84}$ There is also some protection for self-incrimination by witnesses. ${ }^{85}$

Although the Rules do not provide for them, the ICTY has recognised evidentiary privileges for state officials, ${ }^{86}$ the Commander of the United Nations Special Forces, ${ }^{87}$ tribunal officials, ${ }^{88}$ and for the personnel of the International Committee of the Red Cross (ICRC). ${ }^{89}$ In the latter case, the Trial Chamber found that the important role of the ICRC is recognised in customary international law, ${ }^{90}$ and that in order to carry out its functions it depends on its workers maintaining perceptions of their neutrality and independence in conflict zones, ${ }^{91}$ and on their honouring of promises of confidentiality. ${ }^{92}$

The absolute privilege for ICRC personnel is intrinsically connected to international humanitarian law and international justice, and is justified by the need to protect the strong public

83 Rules of Procedure and Evidence, above n 8, Rule 97 provides that "[a]ll communications between lawyer and client shall be regarded as privileged, and consequently not subject to disclosure at trial."

84 ICTY Statute, above n 43, Art 21(g) provides that a defendant has the right "not to be compelled to testify against himself or to confess guilt." See also ICTR Statute, art 20.

85 Rules of Procedure and Evidence, above n 8, Rule 90(E).

86 Prosecutor v Blaskic Case No IT-95-14-AR (29 October 1997, Appeals Chamber) "Judgement on the Request of the Republic of Croatia for a Review of the Decision of Trial Chamber II of 18 July 1997", paras 38 and 43 (finding that "both under international law and the Statute itself, Judges or Trial Chambers cannot address binding orders to State officials."). The Tribunal can, however, issue binding orders and requests to the State itself in accordance with article 29 of the ICTY Statute.

87 Prosecutor v Blaskic Case No. IT-95-21-AR (12 May 1999, Trial Chamber) "Decision of Trial Chamber I on Protective Measures for General Philippe Morillon, Witness of the Trial Chamber."

88 Prosecutor v Delalic Case No. IT-96-21-T (8 July 1997, Trial Chamber) "Decision on the Motion Ex Parte by the Defence of Zdravko Mucic Concerning the Issue of a Subpoena to an Interpreter", para 20 (finding that it is an "important consideration in the administration of justice to insulate the interpreter or other functionaries of the International Tribunal from constant apprehension of the possibility of being personally involved in the arena of the conflict, on either side, in respect of matters arising from the discharge of their duties. On both these grounds, the interests of justice frowns upon any of the parties being able to call an interpreter as a witness.").

89 Prosecutor v Simic, above n 59.

Prosecutor v Simic, above n 59, paras 46-50, 72.

91 Prosecutor v Simic, above n 59, para 52.

92 Prosecutor v Simic, above n 59, para 56. 
interest in the work of the ICRC. That there is a public interest in protecting the newsgathering ability of journalists is similarly recognised in the domestic realm, where various formulations of journalistic privilege have arisen through an application of Wigmore's criteria, in statutes, and by virtue of constitutional guarantees of the right to freedom of expression.

\section{Journalists' Privilege in Other Jurisdictions}

Although there is some uncertainty with regard to the impact on the judges' rulemaking powers resulting from general principles of law, in cases of first instance such as Randal's case it is important to consider the approaches of other jurisdictions that have dealt with similar issues. That this is the case is evident from the fact that the Rules of the Tribunals seek to incorporate the principles of various legal systems, and particularly from the reference to general principles of law in Rule 89(B). The Tribunal could justifiably examine "[a] combination of rules of different countries, which have crystallised into a general rule; a particular rule from one or more countries that is reflective of a more general rule; or the reasoning underpinning such rules."93 The following therefore seeks to determine the content of these aspects in relation to journalistic privilege.

\section{The United States of America}

The United States has the most developed jurisprudence regarding journalistic privilege. Although the courts were historically against the recognition of a journalistic privilege under common law, ${ }^{94}$ and on the basis of the Constitution's First Amendment right to freedom of expression, ${ }^{95}$ a majority of states provided varying degrees of protection for journalists through statutory 'shield laws'. ${ }^{96}$ Although there is no such law at the federal level, ${ }^{97}$ the Justice Department

93 Dixon, above n 46, 99.

94 Journalists' claims to privilege based on professional ethics and duties to sources were rejected by the courts. See, for example, Plunkett v Hamilton (1911) 70 S E 781, 785-786 (Ga)

95 US Constitution, amendment I states that "Congress shall make no law...abridging the freedom of speech." A journalist first claimed a privilege against revealing sources based on the First Amendment in 1958, and the court rejected this. Garland v Torre (1958) F 2d 545 (2d Cir).

96 Ala Code § 12-21-142 (Supp 1998); Alaska Stat § 09.25.300-09.25.390 (Michie 1998); Ariz Rev Stat Ann § 12-2237 (Supp 1999); Ark Code Ann § 16-85-510 (Michie 1987); Cal Evid Code § 1070 (Supp 2000); Colo Rev Stat § 13-90-119 (Bradford 1999); Del Code Ann, title 10, § 4320-4326 (Michie 1999); DC Code Ann $\S 16-4701$ to 16-4704 (Supp 1998); Fla Stat Ann § 90.5015 (Supp 2000); Ga Code Ann § 24-9-30 (Supp 1999); Ill Comp Stat Ann § 5/8-901 to 5/8-909 (Supp 1999); Ind Code Ann § 34-46-4-1 to 34-46-4-2 (Westlaw 1999); Ky Rev Stat Ann § 421.100 (Supp. 1999); La Rev Stat Ann § 1451-1459 (Supp 2000); Mich Comp Laws § 767.5a (Supp 1999); Minn Stat Ann § 595.021 to 595.025 (Supp 2000); Mont Code Ann § 26-1-901 to 26-1-902 (Supp 1999); Neb Rev Stat § 20-144 to 20-147 (Supp 1997); Nev Rev Stat § 49.275 (Supp 1999); NC Gen Stat § 8-53.11 (Supp 1999); ND Cent Code § 31-01-06.2 (Supp 1999); NJ Stat Ann § 2A:84A-21 to 2A:84A-21.13 (Westlaw 1994); NM Evid Rules § 11-514 (Michie 1994); NY Civ Rights Law § 79-h (Supp 1999); Ohio Rev Code Ann § 2739.04 and 2739.12 (Supp 1999); Okla Stat Ann title 12, § 2506 (Westlaw 1993); Or Rev Stat Ann § 44.510 to 44.540 (Supp 1998); 42 Pa Cons Stat Ann § 5942 (Supp 1999); RI Gen Laws § 9-19.1-1 to 9-19.1-3 (1998); SC Code Ann § 19-11-100 (Supp 1999); 
has set out guidelines for federal prosecutors with regard to subpoenaing journalists. ${ }^{98}$ These guidelines largely provided the basis for the tests put forward by both Randal and the amici. ${ }^{99}$

Only one journalists' privilege case has been heard by the United States Supreme Court. ${ }^{100}$ In deciding not to recognise a qualified privilege, Justice White's majority judgment in Branzburg $v$ Hayes put considerable emphasis on the "longstanding principle that 'the public ... has a right to every man's evidence."'101 It was held that the First Amendment did not invalidate any "incidental burdening" of the press caused by the enforcement of laws that applied to all citizens. ${ }^{102}$

Justice Powell provided a concurring opinion. ${ }^{103}$ It was an interesting concurrence, however, in that while it did not explicitly go against the majority, it also clearly supported a journalistic privilege in certain situations. He suggested that "if the newsman is called upon to give information bearing only a remote or tenuous relationship to the subject of the investigation, or if he has some other reason to believe that his testimony implicates a confidential source relationship without legitimate need of law enforcement, he will have access to the court on a motion to quash." ${ }^{104}$ Each

Tenn Code Ann § 24-1-208 (Supp 1999). The first shield law was passed in Maryland in 1896. A common requirement in these state laws is that the information sought must be "critical or necessary" to a claim.

97 See generally Mark Neubauer "The Newsman's Privilege after Branzburg: The Case for a Federal Shield Law" (1976) 24 UCLA L Rev 160.

9828 CFR § 50.10. The regulations were formally included as part of the Code of Federal Regulations on 16 October 1973. See Adam Liptak "The Hidden Federal Shield Law: On the Justice Department's Regulations Governing Subpoenas to the Press" (1999) Ann Surv Am L 227, 232. The regulations require that the Attorney General must give authorisation before a subpoena is issued. See 28 CFR § 50.10(e). They are not intended to be enforced by the courts. See Shain v Long (1992) F 2d 850, 854 ( $\left.4^{\text {th }} \mathrm{Cir}\right)$. Arguably, however, they serve as a "shadow federal shield law." Liptak, 236.

99 The guidelines require that "all reasonable attempts should be made to obtain information from alternative sources." 28 CFR $\S 50.10(b)$. They also state that subpoenas "should not be used to obtain peripheral, nonessential, or speculative information." § 50.10(f)(2). Furthermore, as reflected in the proposal of the amici in Randal's case, they require, in the context of criminal trials, that "there should be reasonable grounds to believe ... that the information sought is essential to a successful investigation - particularly with reference to directly establishing guilt or innocence." § 50.10(f)(2).

100 Branzburg $v$ Hayes (1972) 408 US 665. This case resulted from the consolidation of three cases on appeal from federal appellate courts: Caldwell $v$ United States (1970) 434 F 2d 1981 (9 $9^{\text {th }}$ Cir) (in which a First Amendment privilege was recognised by an appellate court for the first time); Branzburg $v$ Pound (1971) 461 S W 2d 345 (Ky) and Branzburg v Meigs (1971) 503 S W 2d 748 (Ky) (these two cases were heard together at the federal appeal level, where the court held that the state shield law did not apply where the journalist had been a witness to criminal activity); and In Re Pappas (1971) 266 N E 2d 297 (Mass).

101 Branzburg v Hayes, above n 100, 686 Justice White (quoting Wigmore, above n 82, vol 8 § 2192).

102 Branzburg v Hayes, above n 100, 682-683 Justice White.

103 This meant that the three judges who joined Justice White (as well as Justice Powell who partially concurred) achieved a 5:4 majority against the recognition of a journalistic privilege.

104 Branzburg v Hayes, above n 100, 710 Justice Powell. 
claim should therefore be judged on a case-by-case basis involving the balancing of the competing interests of freedom of the press and the duty to testify. ${ }^{105}$

The main dissenting judgment was that of Justice Stewart, ${ }^{106}$ who argued that the decision of the majority would lead authorities to "annex the journalistic profession as an investigative arm of the government," therefore endangering the media's autonomy. ${ }^{107} \mathrm{He}$ held that the right of journalists to protect confidential sources was rooted in the essential societal interest in the "full and free flow of information to the public."108 He therefore set out a three-pronged test, which required the following elements to be shown before a journalist was subpoenaed: ${ }^{109}$

(1) that there is probable cause to believe that the newsman has information that is clearly relevant to a specific probable violation of law;

(2) that the information sought cannot be obtained by alternative means less destructive of First Amendment rights; and

(3) a compelling and overriding interest in the information.

Despite the majority's finding that no First Amendment-based privilege existed, in ten of the twelve circuits federal appeals courts have explicitly recognised such a privilege. ${ }^{110}$ In setting out the factors to be considered in balancing the First Amendment interests and the needs of justice, some courts have even established tests very similar to that proposed by Justice Stewart. ${ }^{111}$

In some jurisdictions, the factors or tests that are considered in cases involving confidential sources are similarly applied where the information sought is non-confidential. ${ }^{112}$ These courts

105 Branzburg v Hayes, above n 100, 709-710 Justice Powell.

106 A separate dissenting opinion was written by Justice Douglas who argued that the journalist's privilege should be absolute. See Branzburg v Hayes, above n 100, 712.

107 Branzburg v Hayes, above n 100, 725 Justice Stewart.

108 Branzburg v Hayes, above n 100, 725 Justice Stewart.

109 Branzburg $v$ Hayes, above n 100, 743 Justice Stewart.

110 In particular, the First, Second, Third, Fourth, Fifth, Seventh, Tenth, and DC Circuits, also the Ninth and Sixth Circuits, although the results are less clear in these latter two jurisdictions. For detailed information and analysis of the law relating to journalists' privilege in the United States see the website of the Reporters' Committee for Freedom of the Press < www.rcfp.org/privilege> (last accessed 15 August 2003).

111 See United States v Burke (1983) 700 F 2d 70 (2d Cir); Riley v City of Chester (1979) 612 F 2d 708, 716717 (3d Cir); Shoen v Shoen (1995) 5 F 3d 1289 (9 $9^{\text {th }}$ Cir); Silkwood v Kerr-McGee Corp (1977) 563 F 2d 433, 438 (10 ${ }^{\text {th }}$ Cir) United States $v$ Caporale (1986) 806 F 2d 1487, 1504 (11 ${ }^{\text {th }}$ Cir); Maughan $v$ NL Industries (1981) 524 F Supp 93, 95 (DC Cir).

112 See Church of Scientology (1993) 992 F 2d 1329 (4 ${ }^{\text {th }}$ Cir); Loadholtz v Fields (1975) 389 F Supp 1299, 1303 (MD Fla); Kidwell v McCutcheon, (1996) 962 F Supp 1477, 1480 (SD Fla); Maughan v NL Industries (1981) 524 F Supp 93, 95 (DC Cir). The Justice Department guidelines, and a number of state shield laws, 
generally consider that the "chilling effect" of disclosure is the same regardless of the type of information sought, ${ }^{113}$ yet other decisions have applied a lower threshold for overcoming the First Amendment-based privilege in cases where non-confidential information is sought, or have otherwise considered this a factor in a balancing exercise. ${ }^{114}$ Some courts have also held that no privilege exists unless confidential sources are involved. ${ }^{115}$ As a result, the law in this area is very uncertain.

In criminal cases it may be said that although a privilege is still available on the basis of First Amendment guarantees, particular interests concerning the administration of justice might outweigh this. ${ }^{116}$ Despite the fact that the interests of defendants, in terms of due process rights, are guaranteed by the Constitution, ${ }^{117}$ one commentator has found that the tests applied by the federal

also do not differentiate between confidential and non-confidential information. For an overview of the law regarding the journalists' privilege for non-confidential information see Anthony L Fargo "Reconsidering the Federal Journalist's Privilege for Non-Confidential Information: Gonzales v NBC" (2001) 19 Cardozo Arts and Ent L J 355.

113 See Von Bulow by Auersperg v Von Bulow (1987) 811 F 2d 136, 145 (2d Cir) (stating that there is no particular difference between the need to protect confidential and non-confidential information); United States $v$ Cuthbertson (1980) 630 F 2d 139, 147 (3d Cir) (holding that any forced disclosure of information could "undercut the public policy favouring the free flow of information to the public."); Loadholtz $v$ Fields (1975) 389 F Supp 1299, 1303 (MD Fla) (stating that "compelled production of a reporter's resource materials is equally as invidious as the compelled disclosure of his confidential informants," and that the "chilling effect" on the flow of information was equally as harmful even without the presence of a confidential source); Maughan v NL Industries (1981) 524 F Supp 93, 95 (DC Cir) (noting that compelling a reporter to produce notes no doubt constitutes a "significant intrusion into and certainly a chilling effect upon the newsgathering and editorial process," and thus "compelled production of materials is equally as invidious as the compelled disclosure of ... confidential informants.").

114 United States $v$ The LaRouche Campaign (1981) 841 F 2d 1176, 1181 (1 ${ }^{\text {st }}$ Cir); Russo v Geagan (1983) 35 Fed R Serv 2d 1403 (D Mass); Gonzales v National Broadcasting Co (1999) 194 F 3d 29 (2d Cir); Doe v Kohn, Nast and Graf (1994) 853 F Supp 147, 149-150 (ED Pa); Warnell v Ford Motor Co (1998) 183 FRD 624, 625 (ND Ill); Shoen $v$ Shoen (1995) 5 F 3d 1289 ( $9^{\text {th }}$ Cir).

115 See Lynch $v$ Riddell (1982) 35 Fed R Serv 2d 185 (D Mass); United States v Smith (1998) 135 F 3d 963, 971 ( $5^{\text {th }}$ Cir $)$.

116 See Parsons $v$ Watson (1991) 778 F Supp 214, 218 (D Del); Re Shain (1992) 978 F 2d 850 (4 Cir); United States v Jennings (21 June 1999) 97 CR 765, WL 438984 (ND Ill); Farr v Prichess (1975) 522 F 2d 464, 468 ( $9^{\text {th }}$ Cir); United States $v$ Hubbard, (1979) 493 F Supp 202, 205 (DC Cir). In the only case where the special position of war correspondents has been raised, the district court in United States $v$ Lindh (2002) 210 F Supp 2d 780 (ED Vir) considered this to be a "novel argument," but found that the journalist's testimony was material to a "non-frivolous" issue, and further that the asserted privilege was outweighed by the need to protect the defendant's fair trial rights.

117 US Constitution, amendment VI provides that "[i]n all criminal prosecutions, the accused shall enjoy the right to a speedy and public trial, by an impartial jury of the state and district wherein the crime shall have been committed, which district shall have been previously ascertained by law, and to be informed of the nature and cause of the accusation; to be confronted with the witnesses against him; to have compulsory process for obtaining witnesses in his favour, and to have the assistance of counsel for his defence." 
appeals courts often depend on the identity of the subpoenaing party, and actually make it more difficult for defendants to obtain information from journalists compared to the prosecution. ${ }^{118}$

\section{United Kingdom/Europe}

The common law has never recognised the existence of a specific public interest privilege for journalists. ${ }^{119}$ In the United Kingdom, a statutory qualified privilege for journalists' confidential sources is set out in the Contempt of Court Act 1981:120

No court may require a person to disclose, nor is any person guilty of contempt of court for refusing to disclose, the source of information contained in a publication for which he is responsible, unless it is established to the satisfaction of the court that disclosure is necessary in the interests of justice or national security or for the prevention of disorder or crime.

The most significant case regarding the application of this rule is Goodwin $v$ United Kingdom. ${ }^{121}$ The plaintiff journalist took his complaint to the European Court of Human Rights arguing that his right to freedom of expression, as guaranteed by article 10 of the European Convention on Human Rights, ${ }^{122}$ had been restricted by the order of the domestic court that he reveal a confidential source, and its subsequent finding of contempt when he refused to do so. ${ }^{123}$

118 Schmid, above $\mathrm{n}$ 81, 1458. Schmid argues that in the majority of cases where the subpoenaing party has been either the prosecutor or a grand jury, the courts have applied Justice White's bad faith requirement, which places the burden on the journalist to show that a privilege should apply. This is in contrast to the approach used in the majority of cases where the defendant has requested the information, where the courts have preferred either a flexible balancing test or one similar to Justice Stewart's three-pronged test, which place some or all of the burden on the shoulders of the subpoenaing party, and which generally result in a higher threshold for ordering journalists' testimony.

119 New Zealand Law Commission Evidence Law: Privilege (NZLC PP23, Wellington, 1994) 135. See Attorney General v Mulholland [1963] 1 All ER 767 (CA); British Steel Corp v Granada Television Ltd [1981] AC 1096 (HL).

120 Contempt of Court Act 1981, s 10.

121 Goodwin v United Kingdom, above n 18.

122 European Convention for the Protection of Human Rights and Fundamental Freedoms (4 November 1950) 213 UNTS 222 ["European Convention on Human Rights"]. Article 10(1) provides: "Everyone has the right to freedom of expression. This right shall include freedom to hold opinions and to receive and impart information and ideas without interference by public authority and regardless of frontiers." It is uncertain whether s 10 was formulated in recognition of the United Kingdom's obligation to protect freedom of expression as a result of its ratification of the European Convention on Human Rights. But see Ashworth Hospital Authority v MGN Ltd [2002] 4 All ER 193, 203 (HL) (stating that "whatever was the objective of those promoting s 10, there can be no doubt now that both s 10 and art 10 have a common purpose in seeking to enhance the freedom of the press by protecting journalistic sources.")

123 X Ltd v Morgan-Grampian (Publishers) Ltd and Ors [1991] 1 AC 1 (HL). 
Finding that forced disclosure of confidential sources was a restriction of the right to freedom of expression, ${ }^{124}$ the Court went on to consider the permissibility of such a limitation and therefore whether disclosure was "justified by an overriding public interest."125 The criteria used were those which had been applied in earlier cases, and which are derived from the wording of the European Convention on Human Rights. The limitation on the right must be provided by law, pursue a legitimate aim, and be "necessary in a free and just society."126 This final criteria has been interpreted to require that the "pressing social need" for the restriction must be "convincingly established," and that the measures taken must be proportionate to the legitimate aim pursued. ${ }^{127}$ The Court found that, in the circumstances of the Goodwin case, there was not a "reasonable relationship of proportionality between the legitimate aim pursued by the disclosure order and the means deployed to achieve that aim" since the party seeking disclosure had already obtained other measures to protect their interests. ${ }^{128}$ Thus the restriction of the right to freedom of expression arising from the particular application of the statute in this situation was not permissible under the Convention.

Domestic courts have subsequently applied the reasoning in Goodwin, but it can generally be seen that the threshold that disclosure be "necessary in the interests of justice" is quite low. ${ }^{129}$ The courts have not set out a clear standard regarding the weight of the public interest in the free flow of information, instead finding that the level of public interest will vary from case to case, as will the

124 Goodwin, above n 18, para 70. The court held that "[p]rotection of journalistic sources is one of the basic conditions of press freedom... Without such protections, sources may be deterred from assisting the press in informing the public on matters of public interest. As a result, the vital public watchdog role of the press may be undermined and the ability of the press to provide accurate and reliable information may be adversely affected."

125 Goodwin, above n 18, para 70.

126 Article 10(2) provides that the exercise of the right to freedom of expression "may be subject to such formalities, conditions, restrictions or penalties as are prescribed by law and are necessary in a free and democratic society, in the interests of national security, territorial integrity or public safety, for the prevention of disorder or crime, for the protection of health or morals, for the protection of the reputation or rights of others, for preventing the disclosure of information received in confidence, or for maintaining the authority and impartiality of the judiciary."

127 See Handyside v United Kingdom (1980) 1 EHRR 737, para 50; The Sunday Times v United Kingdom (1980) 2 EHRR 245, para 59.

128 Goodwin, above n 18, para 46.

129 Despite the finding in Goodwin, above n 18, para 45 that "it will not be sufficient, per se, for a party seeking disclosure of a source to show merely that he or she will be unable without disclosure to exercise a legal right or avert the threatened legal wrong on which he or she bases his or her claim in order to establish the necessity of disclosure," recent decisions have found an exceptional need for the information to be shown in situations where a party requires disclosure in order to bring an action. See John $v$ Express Newspapers [2000] 3 All ER 257 (CA); Ashworth Hospital Authority v MGN Ltd [2002] 4 All ER 193 (HL). 
strength of the interest in disclosure. ${ }^{130}$ One factor that has been considered in a number of cases, however, is whether the person seeking disclosure has made attempts to obtain the evidence through other means. ${ }^{131}$

\section{New Zealand and Australia}

In New Zealand and Australia the courts "have not worked out a coherent policy to deal with the protection of journalists' sources."132 There are a number of overlapping rules that might apply depending on the circumstances, ${ }^{133}$ but ultimately the discretion is with the court to compel disclosure or not.

The Australian courts put little emphasis on the effect of forced disclosure on freedom of expression, finding that there is very limited constitutional guarantee of such a right. ${ }^{134}$ In John Fairfax \& Sons Ltd v Cojunagco the judge found strongly against the existence of a journalistic privilege, stating that "there is a paramount interest in the administration of justice which requires that cases be tried by courts on the relevant and admissible evidence," and that "[t]he role of the media in collecting and disseminating information to the public does not give rise to a public interest" which can be allowed to prevail over this. ${ }^{135}$

Such statements reveal the impact of Wigmore's criteria for the formulation of a new privilege, ${ }^{136}$ as do the statutory provisions of the two countries. ${ }^{137}$ In New Zealand, journalists

130 See Interbrew SA v Financial Times Ltd and Ors [2002] 1 Lloyd's Rep 542, para 32. Some factors to consider are "the nature of the confidence (if any) placed by the source in the press, whether his communication to the press can reasonably be considered by him and by the public at large as having been made in the expectation of the preservation of confidentiality, the apparent purpose for his communication to the press and the public interest in shielding that source from exposure."

131 See John v Express Newspapers, above n 129; Saunders v Punch Ltd [1998] 1 All ER 234 (CA).

132 New Zealand Law Commission Evidence Law: Privilege (NZLC PP23, Wellington, 1994) 132.

133 For example, at common law the so-called 'newspaper rule' can prevent disclosure in the limited circumstances of preliminary motions for discover in defamation actions where a member of the press is a party. See Attorney-General v Clough [1963] 1 All ER 420 (QB); Broadcasting Corporation of New Zealand v Alex Harvey Industries Ltd [1980] 1 NZLR 163 (CA); Brill v Television Service One [1976] 1 NZLR 683 (HC); European Pacific Banking Corporation v Forth Estate Publications Ltd [1993] 1 NZLR 559 (CA). This protection does not extend to the trial, despite findings that the overriding justification for the newspaper rule is the public interest in the dissemination of information, which would seemingly be affected by disclosure regardless of the stage of proceedings.

134 See Lange v Australian Broadcasting Corp (1997) 189 CLR 520, 560-562. This guarantee has been found to be important in situations involving communication about government or political matters, but the courts have indicated that the level of protection is not particularly high where other matters are concerned. See also NRMA v John Fairfax Publications Pty Ltd (26 June 2002) NSWSC 563 44541/01.

135 John Fairfax and Sons Ltd v Cojuangco (1988) 165 CLR 346, 354.

136 See Donald L Mathieson (ed) Cross on Evidence (7 ed, Butterworths, Wellington, 2001) 338. 
might be able to claim a privilege for confidential communications under section 35 of the Evidence Amendment Act (No 2) $1980 .{ }^{138}$ This provision places the burden on the party seeking to withhold information to satisfy the court that the public interest in disclosure is outweighed by the public interest in preserving particular confidences. In determining this courts can take into account: ${ }^{139}$

(a) The likely significance of the evidence to the resolution of the issues to be decided in the proceeding;

(b) The nature of the confidence and of the special relationship between the confidant and the witness;

(c) The likely effect of the disclosure on the confidant or any other person.

The New Zealand Law Commission considered that the courts should not require that the public interest in freedom of the press and the confidentiality of its sources be established in each case. Instead, the "free flow of information (and, by implication, the freedom of the press) should be declared a matter of public interest" covered by the section. ${ }^{140}$ The Commission therefore did not consider that there was a need for a separate provision for journalists. It did, however, recommend additional guidelines. These were that "alternative avenues should be exhausted before ordering a journalist to disclose; a court should take into account the nature of the proceeding, such as whether it is criminal or civil; and it should also consider whether disclosure can occur in a manner which limits publication, such as through inspection by the court or name suppression."141

137 Evidence Amendment Act (No 2) 1980, s 35 (New Zealand). In Australia, the Evidence Act 1995, ss 126A126B (NSW) is the only one containing a general privilege provision. Other statutes contain specific provisions for particular communications where there is considered to be a public interest in limiting disclosure. See Evidence Act 1977, ss 10-14 (Qld); Evidence Act 1958, ss 26-32 (Vic); Evidence Act 1995, ss $117-128$ (Cth).

138 Privacy Act 1993 generally exempts news activities from its ambit (section 2 "agency" (1)(xiii)). In addition, section 28(1)(g) also provides limited protection for journalists, but only extends to the ability of state broadcasters (Radio New Zealand Ltd and Television New Zealand Ltd) to refuse to disclose sources of information where this information was received in confidence, or where disclosure would prejudice the future supply of such information.

139 Evidence Amendment Act (No 2) 1980, s 35. The Evidence Act 1995 (NSW) is more detailed with regard to these considerations. Under s 126B(4) the court can consider: "(a) the probative value of the evidence in the proceeding; (b) the importance of the evidence in the proceeding; (c) the nature and gravity of the relevant offence, cause of action or defence and the nature of the subject matter of the proceeding, the availability of other evidence concerning the matters to which the protected confidence or protected identity information, including the likelihood of harm, and the nature and extent of harm that would be caused to the protected confider; (f) the means ... available to the court to limit the harm or extent of the harm that is likely to be caused if the evidence of the protected confidence or protected identity information is disclosed; (g) if the proceeding is a criminal proceeding whether the party seeking to adduce the evidence of the protected confidence or protected identity information is a defendant or prosecutor; (h) whether the substance of the protected confidence or the protected identity information has already been disclosed by the protected confider or any other person."

140 New Zealand Law Commission Evidence Law: Privilege (NZLC PP23, Wellington, 1994) 139-140.

141 New Zealand Law Commission, above n 140, 140. 
There has been very little litigation involving this section, and none in respect of journalists' confidential information. There has also been no case involving a claim for protection under section 14 of the Bill of Rights Act 1990, ${ }^{142}$ despite this potential scope for a rights-based argument. ${ }^{143}$

\section{Canada}

In contrast to New Zealand and Australia, the courts in Canada have recognised that a form of privilege may arise from the application of the right to freedom of expression as contained in the Canadian Charter of Rights and Freedoms. ${ }^{144}$ In $R v$ Hughes, the Supreme Court of British Columbia held that "the special position of the media, including the constitutional guarantee of freedom of the press, should be balanced against a litigant's right to receive the disclosure of information, including confidential sources, by members of the media."145 In the context of this case, where the subpoena was sought by the accused, the right of the accused to "make full answer and defence" was a legitimate concern for the court to consider in determining the correct balance. ${ }^{146}$ The judge set out a list of further factors that required consideration in the balancing exercise: ${ }^{147}$

(a) [T] he relevance and materiality of the evidence to the issues at trial; ... (c) the probative value of the evidence; (d) whether the evidence is available through any other means and if so, whether reasonable efforts have been made on the part of the accused to obtain the evidence from that other source; (e) if the media's ability to gather and report the news will be impaired by being called to give evidence and if so, the degree to which it is impaired; (f) whether the necessity of the evidence in the case at hand outweighs the impairment, if any, of the role of the media; and (g) whether the impairment of the media's function can be minimised by confining the evidence adduced to only that which is necessary to the accused's case and his right to make full answer and defence.

142 New Zealand Bill of Rights Act, 1990, s 14 provides: "Everyone has the right to freedom of expression, including the freedom to seek, receive, and impart information and opinions of any kind in any form."

143 New Zealand Law Commission, above n 140, 134.

144 Canadian Charter of Rights and Freedoms, Part I of the Constitution Act 1982 (Canada Act 1982 (UK), sch B). Section 2(b) provides that everyone has the right to "freedom of thought, belief, opinion and expression, including freedom of the press and other media of communication."

$145 R v$ Hughes (A) et al (14 July 1998) British Columbia Supreme Court Vancouver CC971180, para 54 Romilly J. Although the court considered this exercise within the context of the Charter, the judge stated that "this principle is not dependant upon the Charter and in fact predates the Charter." $R v$ Hughes, para 55.

$146 R v$ Hughes, above $\mathrm{n} 145$, para 60 . In fact, the necessity of the evidence to the accused's case and his right to make full answer and defence was considered to be "perhaps the most important factor" since it touches on a constitutional right. $R v$ Hughes, above n 145, para 69.

$147 R v$ Hughes, above $\mathrm{n}$ 145, para 66. These factors were subsequently applied in $R v$ Erickson [2002] OJ No 3341. 
Having found that the impact on freedom of expression in this case did not outweigh the accused's right to defend the charges against him, ${ }^{148}$ in part because the information was not confidential and thus the impact was considered to be reduced, ${ }^{149}$ the judge then went on to consider the application of Wigmore's four conditions for the recognition of a privilege. Even assuming that the first three elements were satisfied, the judge held that a claim for qualified privilege was not made out. ${ }^{150}$ This was because it could not be shown that the harm to the relationship between journalist and source was greater than the benefits of disclosure to the administration of justice in this case. ${ }^{151}$

\section{How Does the Appeals Chamber Test Compare?}

It is clear from the domestic approaches that there is no absolute testimonial privilege for journalists, ${ }^{152}$ regardless of whether the source of the rule is statutory or constitutional protection, or results from the application of Wigmore's criteria. In all instances the underlying justification for the recognition of a privilege is the desire to protect the public interest in the free flow of information. The focus is on balancing this interest in some way with the interests inherent in the administration of justice. Indeed, the limited and incoherent nature of the New Zealand and Australian approaches might be explained by the absence of strong constitutional protection of the right to freedom of expression in comparison to the three other jurisdictions examined, and therefore the balance will favour disclosure in most cases.

In terms of the possible applications of general principles of law set out above, the public interest in protecting freedom of expression is "the reasoning underpinning" the rules in domestic courts. ${ }^{153}$ Furthermore, regardless of the approach used in formulating these rules, domestic courts engage in a balancing exercise. Two identifiable factors in this exercise are the importance of the information sought, and the need to consider other sources before requiring the testimony of

$148 R v$ Hughes, above n 145, paras 82-103.

$149 R v$ Hughes, above $n$ 145, para 101 (holding that "if there is an infringement on the freedom of the press in this case that infringement is not a substantial one.") Note that the fact that the information was nonconfidential did not necessarily preclude the existence of a journalistic privilege.

$150 R v$ Hughes, above $\mathrm{n}$ 145, paras 105-107. The judge found that the first two were difficult to make out in this case due to the non-confidential nature of the relationship, but accepted that the third, regarding the importance of the relationship, applied.

$151 R v$ Hughes, above n 145, para 108.

152 But see some state shield laws in the United States, including those in California and Nevada, and Austrian statutory law, which recognise an absolute privilege for journalists. New Zealand Law Commission Evidence Law: Privilege (NZLC PP23, Wellington, 1994).

153 Although only a limited number of jurisdictions have been considered in this paper this does not in itself go against the finding the general principles of law exist in relation to journalistic privilege. In fact, "general principles of law can be adduced from a single system." Affolder, above n 45, 493. 
journalists. Particular rules that incorporate these, such as the Appeals Chamber test, may therefore be seen as "reflective of a more general rule." These factors also allow for the identification of when there will be a "pressing social need" for the restriction on freedom of expression, as required by a reading of international human rights documents such as the European Convention. ${ }^{154}$ That a balancing of competing interests is inherent in the creation of evidentiary privileges might also be seen as a rule that has "crystallised into a general rule."

There are different opinions in domestic jurisdictions with respect to extending the journalists' privilege to include non-confidential information. A stronger case can be made if a constitutional, or rights-based, approach is used, as there is the potential to argue that freedom of expression is affected by forced disclosure regardless of the type of information sought. In contrast, the traditional law of privilege and resulting statutes focus on the nature of the relationship involved as indicating when the free flow of information might be affected by the disclosure of information.

Although many United States courts have applied a lower threshold for upholding subpoenas where non-confidential information is involved, most do not explain the reason for this. As one commentator has questioned, "[i]f the same First Amendment interests are implicated when both confidential and non-confidential information is subpoenaed, then why does the same test not apply?"155 In this respect, if it is accepted that the effect on freedom of expression is the same in either case, ${ }^{156}$ the Appeals Chamber test in Randal's case can be seen as indicating a consistency that is lacking in the approaches of other jurisdictions.

This consistency is also evident from other features of the Appeals Chamber's approach. For example, there is no indication that a different test will be applied depending on the subpoenaing party. ${ }^{157}$ Furthermore, that the appropriate balance and burden of proof is implicit in the test, rather than through the setting out of various factors that a court may consider on a case-by-case basis, achieves a level of clarity and predictability that is not evident in many domestic approaches. Commentators have emphasised the need for predictable standards in the international tribunals, considering that "lack of predictability was a most troubling problem in the World War II tribunals." 158

154 See Prosecutor $v$ Brdjanin and Talic, above n 27, para 32 Judge Shahabuddeen (stating that "[i]f the evidence was reasonably available from other sources, this suggests that there was no pressing social need for the restriction of the exercise of freedom of expression resulting from compulsion to testify.").

155 Fargo, above n 112, 386-387.

156 See Part V C 3 The impact of compelling testimony.

157 See Part V B Fair Trial Rights.

158 Evan J Wallach "The Procedural And Evidentiary Rules of the Post-World War II War Crimes Trials: Did They Provide An Outline For International Legal Procedure?" (1999) 37 Colum J Transnatl L 851, 882. 
The Appeals Chamber approach is therefore not only an obvious representation of the general principles of law concerning journalistic privilege, it also advances the goal of creating a comprehensive legal framework containing identifiable and clear rules that permit consistent application.

The Appeals Chamber in Randal's case recognised the need to balance the competing interests involved. The following Part examines these interests, and the need for the international tribunals to have regard to them in their work. It seeks to determine whether the Appeals Chamber test achieves a fair and workable balance between them. That is, whether there has been a "fair determination" of the issue in accordance with Rule 89(B).

\section{BALANCING THE COMPETING INTERESTS}

\section{A The Role and Purpose of the International Tribunals}

As set out above, ${ }^{159}$ the international tribunals must have regard to the wording and 'spirit' of their Statutes in resolving procedural issues. As there is nothing in the wording of the Statutes to deny the tribunals the authority to recognise a privilege it is necessary to consider the underlying purposes of the tribunals and their work.

The ICTY has found that its purpose is to "do justice, to deter further crimes, and to contribute to the restoration and maintenance of peace." ${ }^{160}$ Expanding on this, more general justifications for establishing international tribunals include: ${ }^{161}$

- $\quad$ creating an accurate historical record of the events;

- $\quad$ advancing international jurisprudence and the international rule of law;

- $\quad$ identifying guilty individuals to preclude demonisation of entire nations or groups (individualising guilt); and

- $\quad$ achieving justice in the eyes of victims, defendants, and the world community.

It may be considered that the adjudication of criminal allegations with the greatest degree of accuracy possible is of primary importance. ${ }^{162}$ This is because without factually accurate findings

159 Part III A The Ability to Formulate Rules and the Applicable Sources of Law.

160 Prosecutor $v$ Tadic, above n 61, para 18. By 1993, events in the former Yugoslavia led the United Nations Security Council to declare that the atrocities that were occurring constituted a "threat to international peace," and that the creation of an international criminal tribunal would "contribute to the restoration of peace." Security Council Resolution 808 (25 May 1993) UN Doc S/Res/808. These two findings are necessary prerequisites to the United Nations undertaking actions under Chapter VII of its Charter. See United Nations Charter (26 June 1945) 59 Stat 1031, arts 39, 41, 42.

161 McClelland, above n 70, 2.

162 McClelland, above n 70, 5. 
there is the risk of injustice and of doubt regarding findings of guilt, which in turn threatens the legitimacy of the international order and affects the possibility of lasting peace. Obtaining relevant and truthful evidence is therefore a key underlying factor in the ability of the Tribunals to achieve their goals.

The importance of this factor was raised in Randal's case, with the prosecution identifying that there was a threat to the Tribunal's "core fact-finding function" arising from the asserted privilege. ${ }^{163}$ There are, however, other interests at play in the purpose and work of the international tribunals, including the need to act fairly towards all those involved in the process. ${ }^{164}$

In particular, the protection of the accused's fair trial rights is vitally important to ensuring that decisions result from a consideration of the information obtained from both sides. ${ }^{165}$ The accused must therefore be entitled to prepare and present a defence to the charges. Thus the recognition of a privilege not only affects the prosecution's ability to obtain inculpatory evidence, but also implicates the fair trial rights of the accused. ${ }^{166}$ A "central and crucial question" is the extent to which international tribunals must consider international human rights law in formulating such a rule. ${ }^{167}$

\section{B Fair Trial Rights}

The right to a fair trial is a basic human right and a "prominent part of international and regional human rights and humanitarian instruments". ${ }^{168}$ The specific right implicated by the recognition of a testimonial privilege is the right of the accused "to examine, or have examined, the witnesses against

163 Prosecutor v Brdjanin and Talic, above n 6, para 22.

164 See Prosecutor v Brdjanin and Talic, above n 27, para 5 Judge Shahabuddeen.

165 See Christian DeFrancia "Due Process in International Criminal Courts: Why Procedure Matters" (2001) 87 Va L Rev 1381, 1414.

166 This particular aspect was not dealt with separately by either the Trial or the Appeals Chamber in Randal's case, despite it being raised by the prosecution. This may have been because the case was concerned with a prosecution motion, and because the defence did not appear in before the Chambers in relation to the issue, or it may have been because the Chambers considered this issue as being part of the general need for reliable evidence, whether it go towards proof of innocence or of guilt.

167 Goran Sluiter "International Criminal Proceedings and the Protection of Human Rights" (2003) 37 New Eng L Rev 935, 936.

168 Stapleton, above n 63, 560. See Universal Declaration of Human Rights (10 December 1948) GA Res 217, UN Doc A/810, arts 9-11; International Covenant on Civil and Political Rights (19 December 1966) 999 UNTS 171, arts 9, 14-15; African Charter on Human and Peoples' Rights (27 June 1981) 21 ILM 59, arts 3, 6-7; European Convention on Human Rights (4 November 1950) 312 UNTS 221, arts 5-7; American Convention on Human Rights (22 November 1969) 9 ILM 673, arts 7-9. 
him and to obtain the attendance and examination of witnesses on his behalf under the same conditions as witnesses against him". ${ }^{169}$

As noted above, the Appeals Chamber in Randal's case did not indicate any differential treatment depending on the identity of the subpoenaing party. That both the prosecution and the defence should be treated equally and fairly has been recognised by the tribunals in their application of the principle of 'equality of arms', which has been held to be an inherent aspect of the Statutes and Rules. ${ }^{170}$ The prosecution must not be put at any disadvantage that would amount to a procedural inequality in favour of the defence. ${ }^{171}$ The Appeals Chamber test must therefore be applied to defence requests for subpoenas of war correspondents, potentially affecting their ability to present a defence.

This would not on its face violate the terms of the accused's right set out above, since the same conditions apply to the prosecution. The right is further implicated, however, as a result of the tribunals' liberal approach to the admission of evidence. Evidence that is sourced from a journalist may be admitted and considered by the court in its final judgment, despite the defendant not having the opportunity to cross-examine the journalist. ${ }^{172}$ Therefore, as was submitted by the prosecution, the accused's right to cross-examine witnesses was directly at issue in Randal's case. ${ }^{173}$

169 International Covenant on Civil and Political Rights, above n 168, art 14(3)(e). Similar wording is also used in the American Convention on Human Rights, above n 168, art 8(2)(f); European Convention on Human Rights, above n 168, art 6(3)(d). See also First Protocol to the Geneva Convention on the Protection of Victims of Armed Conflicts (1966) UN Doc A/32/144. For general background and discussion of this right see Frank R Herrmann and M Speer Brownlow "Facing the Accuser: Ancient and Medieval Precursors of the Confrontation Clause" (1994) 34 Va J Intl L 481.

170 See Prosecutor v Tadic Case No IT-94-1 (15 July 1999, Appeals Chamber) "Judgment", para 52 (finding that the principle of equality of arms "means that the Prosecution and the Defence must be equal before the Trial Chamber."); Prosecutor v Delalic Case No IT-96-21-T (4 February 1998, Trial Chamber) "Decision on the Prosecution's Motion for an Order Requiring Advance Disclosure of Witnesses by the Defence"; Prosecutor v Aleksovski, above n 75 . In particular, such a finding was made on the basis of article 21(1) of the ICTY Statute, which provides that "[a]ll persons shall be equal before the International Tribunal."

171 Prosecutor v Delalic, above n 170, para 49.

172 In fact, this was the finding of both the Appeals and the Trial Chamber with regard to the admission of Randal's article. See Prosecutor v Brdjanin, above n 35, paras 41-42 (finding that "the Defence challenge to the accuracy of the statements ascribed to the Accused, will, inter alia, be taken into consideration in deciding what weight to ascribe to the Article.").

173 Prosecutor v Brdjanin and Talic, above n 6, para 22. 


\section{International instruments and minimum standards}

Although it is included as a "minimum guarantee" in a number of human rights instruments, ${ }^{174}$ there is little consensus as to whether the right to examine witnesses in fact constitutes a fundamental procedural norm that cannot be derogated from in any circumstances. ${ }^{175}$ The European Court of Human Rights has suggested that proceedings should be considered as a whole in determining whether the accused's right to a fair trial has been violated, ${ }^{176}$ and that there may be situations when the court is required to balance the right to examine witnesses with other interests. ${ }^{177}$ That is, it may not be an automatic breach of fair trial rights to refuse to allow the defence the opportunity to directly cross-examine witnesses, but some way of questioning or challenging a witness should be provided in order for a trial to be fair. ${ }^{178}$

Some commentators have argued that the international criminal courts must vigorously uphold fair trial rights. ${ }^{179}$ This is because protection of the accused's rights is a key factor affecting how the international community will judge the tribunals. ${ }^{180}$ Furthermore, it is argued that it would be

174 See International Covenant on Civil and Political Rights, above n 168, art 14(3); European Convention on Human Rights, above n 168, art 6(3); American Convention on Human Rights, above n 168, art 8(2).

175 For example, "Theodor Meron includes this right among his list of customary procedural norms, but it is excluded in Mani's list of fundamental procedural norms." Affolder, above n 45, footnote 240 (referring to Theodor Meron Human Rights and Humanitarian Norms as Customary Law (Oxford, 1989) 96-96; V S Mani International Adjudication: Procedure Aspects (Martinus Nijhoff, The Hague, 1980) 12).

176 See Doorson v The Netherlands (1996) 22 EHRR 330, para 72 (holding that no violation of the Convention can be found "if it is established that the handicaps under which the defence laboured were sufficiently counterbalanced by the procedures followed by the judicial authorities."). This was the finding in Kostovski $v$ The Netherlands (1989) 12 EHRR 434, para 43. See also Doorson $v$ The Netherlands, para 78 (considering that the task of the European Court is to "ascertain whether the proceedings as a whole, including the way evidence was taken, were fair.").

177 Doorson $v$ The Netherlands, above n 176, para 74 (finding that "while it would clearly have been preferable for the applicant to have attended the questioning of the witnesses," on balance the domestic court was "entitled to consider that the interests of the applicant were outweighed in this respect by the need to ensure the safety of witnesses.")

178 See generally Doorson v The Netherlands, above n 176.

179 Stapleton, above n 63, 545 (arguing that "there is a minimum level of procedural rights below which the ICC cannot go, regardless of the practical impact of the guarantees.").

180 See Falvey, above n 52, 485; Dixon, above n 43, 82; Christian, above n 165, 1383; Lynne Miriam Baum "Pursuing Justice in a Climate of Moral Outrage: An Evaluation of the Rights of the Accused in the Rome Statute of the International Criminal Court" (2001) 19 Wis Intl LJ 197, 197; Vincent M Creta "The Search for Justice in the Former Yugoslavia and Beyond: Analysing the Rights of the Accused Under the Statute and the Rules of Procedure and Evidence of the International Criminal Tribunal for the Former Yugoslavia" (1998) 20 Hous J Intl L 381, 383. Indeed, an aspect of the reluctance of the United States to ratify the Rome Statute establishing the International Criminal Court is the view that citizens would not receive a fair trial in proceedings before the court. See Wald, above n 68, 552. 
unthinkable for the international tribunals to be held to a lesser standard than domestic courts, particularly due to their ability to act as a role model in this regard. ${ }^{181}$

In comparison to domestic courts, however, there are "additional, sometimes countervailing, considerations that make the concept of fair trials particularly complex for international criminal courts." 182

\section{The challenge of protecting fair trial rights in the international tribunals}

Apart from the express desire to protect victims and witnesses, additional complicating factors include the heightened accountability of international tribunals with regard to achieving convictions for crimes of an extreme character, and the strong interests of states in maintaining their powers and prerogatives. ${ }^{183}$ Furthermore, the inherent difficulties in prosecuting these types of crime, which have elements in terms of scale and extent that are far removed from domestic crimes, might call for "extraordinary trial procedures". 184

A key issue with regard to protecting fair trial rights is whether the courts have the necessary capacity to achieve such a goal. Some commentators have argued that the co-operation regime with States that is established by the Statutes has failed to ensure equality between the prosecution and the defence in their ability to procure evidence and witnesses, and therefore present a reasonable case. ${ }^{185}$ Evidence may be beyond the reach of the tribunal because it is unable to successfully coerce the evidence holder, or because the holder deliberately manipulates the release of information. ${ }^{186}$ Such occurrences are seen as having a disproportionate effect on the defence since

181 Cogan, above n 42, 117-118; Stapleton, above $n$ 63, 546. This is also a factor if one of the purposes of the international criminal tribunals is to strengthen the international rule of law. See Part V A The Role and Purpose of the International Tribunals.

182 Cogan, above n 42, 114.

183 Cogan, above n 42, 114.

184 Cogan, above n 42, 115.

185 Cogan, above n 42, 121; McClelland, above n 70, 35; Stapleton, above n 63, 557. The 'co-operation regime' imposes binding obligations on States, as a result of the Statute being contained in a Security Council resolution, to assist the court when specifically requested. This is set out in article 29 of the ICTY Statute which requires States to "co-operate with the International Tribunal in the investigation and prosecution of persons accused of committing serious violations of international humanitarian law." There are loopholes in the Rules, however, which allow for withholding of national security information (Rule 54bis), and other confidential state information (Rule 70).

186 Stapleton, above n 63, 257. According to the counsel for Tadic, "the lack of cooperation displayed by the authorities in the Republika Srpska had a disproportionate impact on the Defence ... . [And accordingly] there was no 'equality of arms' between the Prosecution and the Defence at Trial ... . [T] lack of cooperation was serious enough to frustrate [Tadic's] right to a fair trial." Cogan, above n 42, 124. The same problems exist in Rwanda, where defence counsel have complained for some time about unequal access to, and improper government tampering with, witnesses. See Cogan, above n 182, 129. 
they lack the power, the resources, and the sympathies of governments that the prosecutor has on their side. ${ }^{187}$ Indeed, it may be said that in many cases the need for effective cross-examination becomes particularly important since the "only viable defence may be attacking the credibility and motives of witnesses." 188

Therefore, although the impact of a privilege on the accused's ability to obtain the attendance of war correspondents may not be a technical breach of their fair trial rights, it could be argued that there is the potential for it to amount to a substantive derogation if the test is framed in a way that unfairly restricts a defence.

\section{Rules and decisions of the tribunals}

The Statutes of the tribunals clearly recognise the need to protect the rights of the accused. ${ }^{189}$ Article 21(4)(e) guarantees the right to examine witnesses using the same wording as a number of human rights instruments. ${ }^{190}$ Therefore, in terms of the applicable law for the interpretation of this provision, international documents would appear to be of considerable value. That this is the case is highlighted by the legislative intent in drafting the Statutes as seen in the Report of the SecretaryGeneral regarding the establishment of the ICTY:191

It is axiomatic that the International Tribunal must fully respect internationally recognised standards regarding the rights of the accused at all stages of its proceedings. In the view of the Secretary-General, such internationally standards are, in particular, contained in article 14 of the International Covenant on Civil and Political Rights.

It is important to note that while there are basic ideas of what constitutes a fair trial, and certainly the international documents reflect these, "ideas of due process vary within different

187 Cogan, above n 42, 131; McClelland, above n 70, 35. This is also the case in domestic settings, although perhaps to a lesser degree than in the international tribunals. However, Antonio Cassesse, President of the Tribunal, has "urgently pointed out on several occasions that the scarce resources available to his tribunal make it almost impossible to operate effectively and implement investigations." Quoted in Mercedeh Momeni "Balancing the Procedural Rights of the Accused Against a Mandate to Protect Victims and Witnesses: An Examination of the Anonymity Rules of the International Criminal Tribunal for the Former Yugoslavia" (1997) 41 How L J 155, 173.

188 Stapleton, above n 63, 561.

189 ICTY Statute, above n 43, art 21; ICTR Statute, above n 43, art 20.

190 See Part V B Fair Trial Rights.

191 "Report of the Secretary General Pursuant to Paragraph 2 of Security Council Resolution 808 (1993)" (3 May 1993) UN Doc S/25704, para 106. See Affolder, above n 45, 477 (considering that "[t]he Secretary General's Report containing the Statute and commentary can be regarded as an authoritative source of law for the interpretation of the Statute."); Prosecutor v Tadic, Case No IT-94-1-AR72 (2 October 1995, Appeals Chamber) "Appeal on Jurisdiction" (finding the Report to be "part of the preparatory works of the Statute and the International Tribunal."). 
contexts."192 Part of the 'unique legal framework' of the international tribunals has been the development of standards and approaches with regard to fair trial rights. It can be argued that other international or regional bodies do not engage in the prosecution of individuals, and therefore the international criminal tribunals are embarking on a "maiden voyage" with respect to procedural norms. ${ }^{193}$

The most extensive discussion regarding the application of international standards in interpreting the right to examine witnesses occurred as a result of the ICTY's Protective Measures decision in the Tadic case. ${ }^{194}$ The judges examined the provisions of international human rights documents and their application by other courts, particularly the European Court of Human Rights, and the majority concluded that "the rights of an accused guaranteed under the principle of the right to a fair trial are not wholly without qualification." ${ }^{195}$ It went on to consider that, in the context of the tribunals, "the protection of victims and witnesses is an acceptable reason to limit the accused's right to a fair trial,"196 and that the effect that particular measures have on the right to examine witnesses did not on its own violate the broader right to a fair trial. ${ }^{197}$

The right to examine witnesses is therefore not considered by the Tribunal to be absolute. This is further demonstrated by amendments to the Rules that make it easier to admit affidavit evidence in the absence of cross-examination, ${ }^{198}$ and by decisions to admit transcripts of witness testimony from earlier trials without requiring the witness to appear before the court a second time. ${ }^{199}$ As occurs with the recognition of an evidentiary privilege, the Chambers have sought to balance the right with the other interests involved in the effective administration of justice, and other community

192 DeFrancia, above n 165, 1384 (giving the examples of prisoners of war, conditions of public emergency, and "differing prerogatives of domestic jurisdictions").

193 Dixon, above n 46, 84.

194 Prosecutor $v$ Tadic, above n 61.

195 Prosecutor v Tadic, above n 61, para 61.

196 Prosecutor v Tadic, above n 61, para 36. See also Prosecutor v Delalic Case No IT-96-21-T (28 April 1997, Trial Chamber) "Decision on the Motions by the Prosecution for Protective Measures for the Prosecution Witnesses Pseudonymed 'B' Through to 'M"', para 37 (stating that a concern for witness security is "an acceptable reason to limit the accused's right to a public trial.").

197 Prosecutor v Tadic, above n 61, para 28. See also Prosecutor v Brdjanin and Talic Case No IT-99-36 (3 July 2000, Trial Chamber II) "Decision on Motion by Prosecution for Protective Measures", para 31.

198 See generally Wald, above n 68.

199 See Prosecutor v Aleksovski, above n 75; Prosecutor v Naletilic and Martinovic Case No IT-98-34-PT (27 November 2000, Trial Chamber) "Decision on Prosecution Motion for Admission of Transcripts and Exhibits Tendered During Testimony of Certain Blaskic and Kordic Witnesses". 
interests. ${ }^{200}$ In a number of decisions, however, the judges have stressed that the rights of the accused are a paramount consideration in this exercise, ${ }^{201}$ and that international standards are authoritative in this regard. 202

Nonetheless, as with domestic law and general principles, the jurisprudence developed under regional human rights treaties are not considered binding on the tribunals. ${ }^{203}$ The tribunals can therefore ensure that trials are fair with reference to their special circumstances.

Where the right to obtain and examine witnesses is affected to any degree in the course of the proceedings, the Trial Chamber will take this into consideration in determining the weight to be accorded to particular evidence ${ }^{204}$ and, more generally, in considering whether the accused has been afforded a fair trial. ${ }^{205}$ The duty to weigh evidence could therefore act as an additional "safeguard for the rights of the defendants". 206

Fair trial rights may not be the only human rights that the tribunals will be required to consider in the course of their work. This was recognised in Randal's case when the Trial Chamber stated that it was: ${ }^{207}$

200 See Stapleton, above n 63, 549 (stating that, in the Tadic Protective Measures decision, the Tribunal's attempt "to reconcile sometimes incompatible needs for justice, for protection of victims and witnesses, for a public declaration that the atrocities committed during the conflict were inhumane, and possible, the need for any conviction to convince the international community that the court could be 'effective' contributed to the ICTY's decision to 'balance' the accused's right to a fair trial."). See also Prosecutor v Nicolic Case No IT-94-2-AR73 (5 June 2003, Appeals Chamber) "Decision on Interlocutory Appeal Concerning Legality of Arrest", para 30 (noting that "[t]he correct balance must...be maintained between the fundamental rights of the accused and the essential interests of the international community in the prosecution of persons charged with serious violations of international humanitarian law.").

201 See, for example, Prosecutor v Kordic and Cerkez, above n 45.

202 See Prosecutor v Tadic, above n 191, para 45 (stating that the Tribunal "must provide all the guarantees of fairness, justice and even-handedness, in full conformity with internationally recognised human rights instruments"); Prosecutor v Barayawiza Case No ICTR-96-19 (3 November 1999, Appeal Chamber) "Decision", para 40 (stating that the ICCPR "is part of the general international law and is applied on that basis.")

203 See Prosecutor v Barayawiza, above n 202, para 40 (holding that the jurisprudence of regional human rights bodies "are persuasive authorities which may be of assistance in applying and interpreting the Tribunal's applicable law. Thus, they are not binding of their own accord on the Tribunal. They are, however, authoritative as evidence of international custom.").

204 Rules of Procedure and Evidence, above n 8, Rule 89(D).

205 See Prosecutor $v$ Tadic, above n 170 (in which the defence's first ground of appeal was that there had been an inequality of arms leading to the denial of a fair trial).

206 May and Wierda, above n 45, 755-756.

207 Prosecutor v Brdjanin and Talic, above n 6, para 30. 
[F]ully conscious of its important role in affirming and strengthening international human rights: not only those fundamental rights very often violated in the cases that have come and will continue to come before this Tribunal, not only the substantive and procedural rights of the accused, not only the rights of victims, but also all those other fundamental rights and freedoms that in the course of its work it is called upon to protect, including freedom of expression.

A feature of human rights is that they will inevitably come into conflict with each other, and with other community interests. In the case of war correspondents, the public interest in their work is simultaneously integrated in both the right to freedom of expression and the interests of justice. The information that they obtain regarding acts committed during conflicts can give rise to pressure for the establishment of international tribunals to prosecute those responsible, and can even result in individual indictments.

\section{Freedom of Expression}

1 International human rights and the role of the media

As with fair trial rights, the right to freedom of expression is provided in a number of international and regional human rights instruments. ${ }^{208}$ Article 19 of the Universal Declaration on Human Rights reflects the general wording and substance of these provisions. It states: "Everyone has the right to freedom of expression; this right includes the freedom to hold opinions without interference and to seek, receive and impart information and ideas through any media and regardless of frontiers." 209

In support of its view that there is considerable public interest in the work of war correspondents, the Appeals Chamber in Randal's case emphasised that the right to freedom of expression includes the right to receive information. ${ }^{210}$ Thus it was concerned not only with the rights of journalists themselves, but more generally in those of the international public. In this respect, the Inter-American Court of Human Rights has stated that "when an individual's freedom of expression is unlawfully restricted, it is not only the right of that individual that is being violated, but also the right of all others to 'receive' information and ideas." 211 The role of the mass media is

208 International Covenant on Civil and Political Rights, above n 168, art 19; American Convention on Human Rights, above n 168, art 13; European Convention on Human Rights, above n 168, art 10(1); African Charter on Human and Peoples' Rights, above n 168, art 9.

209 Universal Declaration on Human Rights, above n 168, art 19.

210 Prosecutor v Brdjanin and Talic, above n 27, para 37.

211 Compulsory Membership in an Association Prescribed by Law for the Practice of Journalism (Arts 13 and 29 of the American Convention on Human Rights) Advisory Opinion OC-5/85 (13 November 1985) InterAm Ct HR (Ser A) No 5, para 30. 
therefore particularly important, with the Court considering that "journalism is the primary and principal manifestation of freedom of expression."212

The European Court of Human Rights has also strongly emphasised the importance of the media's role in being able to report freely on matters of public interest. ${ }^{213}$ In Goodwin, the Court considered that the press has a "vital public watchdog" role, ${ }^{214}$ and recalled that "freedom of expression constitutes one of the essential foundations of a democratic society and the safeguards to be afforded to the press are of particular importance,"215

One commentator has emphasised the importance of the media's role in international armed conflicts, and strongly advocated the resulting need to protect journalists: ${ }^{216}$

\footnotetext{
Since in situations of armed conflict it is difficult to enforce international law, journalists' coverage of the performance of the armed parties is of special significance. In fact, since media information influences political attitudes toward armed conflict, what journalists report often contributes toward ensuring respect for the relevant norms of conduct. In most situations of armed conflict, the responsible parties give widely different accounts of the circumstances, and the international community has to rely on journalists to provide relatively unbiased accounts. Thus, the potential for the contribution of journalism to international peace, though indirect, is immense. To the extent that the international community is willing and able to protect journalists covering international conflicts, the cause of international peace is furthered.
}

Thus the public interest in protecting freedom of expression can be seen as particularly strong at the international level. The question that arises is the extent to which this should be taken into account by the international tribunals, and whether the impact on the role of war correspondents from compelling testimony is sufficient to justify special treatment.

\section{Application of the right to the tribunals}

Apart from the possibility that fair trial rights might be violated in the course of the tribunals' functioning, "[o]ther rights might be at stake as well."217 It can be argued that human rights law

212 Compulsory Membership in an Association Prescribed by Law for the Practice of Journalism, above n 211, para 71.

213 See Handyside v United Kingdom, above n 127; The Sunday Times v United Kingdom, above n 127.

214 Goodwin, above n 18, para 70.

215 Goodwin, above n 18, para 39.

216 Amit Mukherjee "International Protection of Journalists: Problem, Practice, and Prospects" (1994) 11 Ariz Intl Comp Law 339, 344.

217 Sluiter, above n 167, 935 (referring to the right to privacy in the context of the execution of search warrants, and the right to freedom of expression being restricted by newspapers being ordered not to publish the names of protected witnesses). 
"binds the tribunals in their activities to the extent that it is part of customary international law or constitutes general principles of law."218 This is because, as creations of international law the international tribunals are subject to that law, and should therefore "abide by peremptory norms of international law under all circumstances and respect other rules of international law when they have not been empowered to deviate from these rules."219

The extensive recognition of the right to freedom of expression in international documents and domestic law, including most notably as a constitutional norm, is strongly indicative of its status as either customary international law or as a general principle. However, the fact that the right is not absolute, and can be derogated from in certain situations involving competing interests, ${ }^{220}$ is a complicating factor in determining the scope and content of the right. ${ }^{221}$ Furthermore, the situations referred to in the international instruments deal with domestic conditions, giving countries scope to consider their own particular needs, and were not intended to apply in the context of an international tribunal applying international law. ${ }^{222}$ Therefore the application of the right to freedom of expression in the Tribunals could justifiably be subject to "the modifications attributable to its peculiar position,"223 and to "the restrictions on the exercise of it which result from the responsibilities and functions of the Tribunal."224

The reliance of the Trial Chamber on the Goodwin case, and its finding that the right to freedom of expression is only affected when journalists are forced to disclose confidential information, suggest that there are no similar impacts resulting from other situations. It may be argued, however, that the distinct and special nature of the work of war correspondents, and its relationship with the international criminal justice system, give rise to a need to consider the right in that context, and the impact of testifying anew.

218 Sluiter, above n 167, 938.

219 Sluiter, above n 167, 938.

220 See International Covenant on Civil and Political Rights, above n 168, art 19(3) which states that "[t]he exercise of the rights provided for in paragraph 2 of this article carries with it special duties and responsibilities. It may therefore be subject to certain restrictions, but these shall only be such as are provided by law and are necessary: (a) For respect of the rights or reputations of others; (b) For the protection of national security or of public order (ordre public), or of public health or morals." Very similar wording is contained in the American Convention on Human Rights, above n 168, art 13(2). See also European Convention on Human Rights, above n 168, art 10(2) in Part IV C 2 United Kingdom/Europe.

221 Sluiter, above n 167, 938.

222 Sluiter, above n 167, 938.

223 Prosecutor v Brdjanin and Talic, above n 27, para 6 Judge Shahabuddeen.

224 Prosecutor v Brdjanin and Talic, above n 27, para 8 Judge Shahabuddeen. 


\section{The impact of compelling testimony}

The principal impact that Randal asserted would result from routinely compelling the testimony of war correspondents was that of the loss of newsgathering ability, and consequently a reduction in the information available to the international community (including international criminal tribunals) regarding events of universal concern. There are three intertwined factors that Randal and the amici argued would contribute to this occurring: the loss of perceived independence, the loss of sources and access to information, and the increase in personal danger for those reporting from conflict areas. The first two provide the general rationale for the recognition of a journalistic privilege in domestic settings. ${ }^{225}$

Although the final factor is not a feature of the arguments in other jurisdictions, it can be seen as an extension of the more general notion that newsgathering is affected by the perception that war correspondents will provide evidence to criminal tribunals. A dramatic description of this impact is contained in the amicus brief, which quotes a media representative as saying that should the tribunals seek the "effective conscription of war reporters as the court's agents, observers and therefore its unarmed foot soldiers" such a policy would be counter-productive, "since a dead witness is of no use to any tribunal." 226

In the context of international criminal justice, the Appeals Chamber similarly recognised that the key feature linking the above factors is that routine testimony shifts the role of war correspondents from being neutral observers to something more akin to international investigative agents, who seek information not only for the public, but directly or indirectly for governments and other bodies as well. ${ }^{227}$ This impact is certainly not dependent on the nature of the information or testimony sought, whether it is published or not, and whether sources expect confidentiality. ${ }^{228}$ That publication in itself affects the views and actions of the international community, and therefore arguably affects personal safety and the ability of war correspondents to continue to gather information, is not the same as the potential extent of the harm caused by the courts relying on their testimony. The Appeals Chamber considered that this because the consequences for the interviewed

225 See generally Schmid, above n 81; Fargo, above n 81.

226 Prosecutor v Brdjanin and Talic, above n 23, para 32.

227 See Prosecutor $v$ Brdjanin and Talic, above n 27, para 43. Louise Arbour, former Prosecutor at the Tribunals, has been quoted as saying that "[t]he international media is often able to gain access to areas where investigators at the tribunals are unable to go .... On the other hand, press access might be cut off if war criminals in positions of power perceived that the international media was pressed into the service of law enforcement." Nina Bernstein "Can War Reporters be Witnesses, Too?" (14 December 2002) The New York Times New York <http://loper.org/ george/trends/2002/Dec/75.html> (last accessed 19 September 2003).

228 See Prosecutor v Brdjanin and Talic, above n 27, para 42. 
persons are much worse if their information is used in testimony against them, as "they may be found guilty in a war crimes trial and deprived of their liberty."229

The Appeals Chamber acknowledged that "it is impossible to determine with certainty whether and to what extent the compelling of war correspondents to testify before the International Tribunal would hamper their ability to work", but considered that the potential impact was so serious that it "could not be lightly discarded".230

Perhaps it was the difficulty in stating definitively what the harm caused by compelled testimony would be that led to war correspondents being provided with a lesser privilege than ICRC workers. Or perhaps it was due to the role of journalists in the international community being seen as less important, or at least less well-defined, compared to that of the ICRC. In any case, the Appeals Chamber did not consider that the impact on this role was sufficient to outweigh the tribunals' need for journalists' evidence outright. The following section examines whether the Appeals Chamber test fairly represents the costs to the competing interests that are acceptable to the international community.

\section{The Appeals Chamber Test: A Fair Balance?}

The Appeals Chamber considered that "society's interest in protecting the integrity of the newsgathering process, and ensuring the free flow of information to the public, is an interest of sufficient social importance to justify the incidental sacrifice of the facts needed in the administration of justice." ${ }^{231}$ Evidently the tests proposed by the amici and by Randal would result in more than merely an incidental sacrifice, and the threshold of the Appeals Chamber test is therefore considerably lower. ${ }^{232}$ That limits on rights and freedoms must be "proportionate to the legitimate aim pursued by the limitation" is a "well-established principle of international and

229 Prosecutor v Brdjanin and Talic, above n 27, para 43. See also Prosecutor v Brdjanin and Talic, above $\mathrm{n}$ 23, para 36: "Even when findings are published and sources known, the link between the forced disclosure and the loss of journalist's independence is compelling, as it significantly changes the tone of journalist's work and the willingness of sources to comply with reporters' requests for interviews." An argument may be made that these statements indicate that the decision is limited to those situations where a war correspondent is called by the Prosecution to give evidence against one of their sources. Such an interpretation would, however, not be in line with the majority of the decision, which deals with the impact of testifying more broadly.

230 Prosecutor $v$ Brdjanin and Talic, above n 27, para 40. Certainly this is a problem in domestic contexts as well. For details regarding studies in this area see Vince Blasi "The Newsman's Privilege: An Empirical Study" (1971) 70 Mich L Rev 229.

231 Prosecutor $v$ Brdjanin and Talic, above n 27, para 35 (quoting Shoen v Shoen (1995) 5 F 3d 1289 (9 Cir). Emphasis added.

232 Prosecutor $v$ Brdjanin and Talic, above n 27, para 47 (considering the requirement that evidence be 'essential' to be too stringent in terms of restricting the availability of evidence). 
national law."233 With regard to the balance between freedom of expression and the legitimate goal of having relevant and reliable evidence available in war crimes trials, the vital importance of the latter justifies encroachment of this right, and therefore the relatively low threshold of the Appeals Chamber test. A higher restriction on obtaining evidence would be incompatible with the purposes of the international criminal tribunals.

In the context of the tribunals, protecting the newsgathering ability of war correspondents serves the broader interests of the international community in international criminal justice, as well as in freedom of expression, and therefore some provision for this group is in line with the 'spirit' of the governing Statutes. Indeed, this is also in the interests of the tribunals themselves.

The testimonial privilege acts to preserve the independence of war correspondents and consequently their reputation as impartial observers. At the same time, a qualified privilege ensures that evidence that is "really significant" is available to the parties and subsequently to the Chambers. ${ }^{234}$ Thus the two limbs of the Appeals Chamber test do not unduly restrict the ability of either the accused or the prosecutor to develop and present their case. In line with the approaches of other jurisdictions, the journalistic privilege is "always subject to an overriding requirement to disclose in the public interest." 235

Any impact that the journalists' privilege will have on the right to obtain witnesses will be minimal and, assuming that the broader right to a fair trial is evident at all stages of the proceedings, it cannot be said that this will result in injustices.

Of greater concern is the residual ability of the Chambers to admit evidence obtained from journalists, even where their actual testimony does not meet the requirements of the Appeals Chamber test. Certainly it is up to the courts, both domestic and international, to determine what evidence can be admitted, ${ }^{236}$ but where this is done without the opportunity for cross-examination there is a very real possibility that perceptions of the fairness of the proceedings will be diminished.

\section{E The Residual Admission of Evidence}

The threat to fair trial rights that arises from admitting evidence sourced from war correspondents arguably results more from the tribunals' lenient approach to admissibility, rather than the decision to formulate a privilege. With relevancy and probative value the only standards for admissibility, the news stories published by war correspondents appear to be valid evidence. That

233 Stapleton, above n 63, 589.

234 Prosecutor v Brdjanin and Talic, above $\mathrm{n} 27$, para 48.

235 Prosecutor v Brdjanin and Talic, above n 6, para 31.

236 See Doorson $v$ The Netherlands, above n 167, para 67 (stating that "the admissibility of evidence is primarily a matter for regulation by national law and as a general rule it is for the national courts to assess the evidence before them."). 
this is the case is further demonstrated by the emphasis that the Trial Chamber placed on the professional status and reputation of both Randal and the Washington Post as being indicative of the reliability of his evidence. ${ }^{237}$ Routinely admitting journalists' research and reports in this manner not only gives rise to the possibility of a trial being perceived as unfair, but also has the potential to undermine the underlying justification for granting a privilege if such reports are subsequently relied on in judgments.

Of course, the judges can determine the weighting to be accorded to evidence with regard to the impact on fair trial rights. It should be expected that the weight to be given to a news article or other written material would be "less than that of a live credible witness subject to cross-examination."238 This has been evident in the few decisions that provide some indication of how the probative value of evidence is assessed. ${ }^{239}$ Furthermore, as in the case of Randal's article, the Trial Chamber will have regard to the claims of the defendant that the evidence is inaccurate. ${ }^{240}$ If this is to result in the trial and final judgment being regarded as fair, the Trial Chamber should be explicit in the weighting that is attributed to the article and the reasons for this. In considering the reliability of the evidence, higher regard should be given to the fact that the author was not subject to cross-examination than to Randal's, or his interpreter's, ${ }^{241}$ professional reputation.

\section{JOURNALISTS' PRIVILEGE IN THE INTERNATIONAL CRIMINAL COURT}

Some commentators argue that the international criminal law of procedure and evidence developed by the ad hoc tribunals will be "one of the main contributions that the Tribunals can

237 Prosecutor $v$ Brdjanin, above n 35, paras 28 and 42. The Trial Chamber considered that the indicia of reliability with regard to the accuracy of the quotes were that "1) Randal is not a lay person randomly asking questions of an individual he just chanced to meet. Randal is a war correspondent seeking out the Accused and conducting an interview with him; 2) Randal was present and interacting with the Accused and could verify his answers on the spot or pursue a similar line of questioning; 3) Randal subsequently published his interview in a reputable newspaper, thus staking his professional reputation on its accuracy ...". This was despite the statement made in its earlier decision that "the objectivity and independence of journalists, and the media that publish their articles or reports, cannot be taken for granted a priori." Prosecutor $v$ Brdjanin and Talic, above n 6, para 42.

238 Wald, above n 61, 551.

239 See Prosecutor v Delalic Case No IT-96-21-T (18 January 1998, Trial Chamber) "Decision on Motion of Prosecution for Admissibility of Evidence"; Prosecutor v Kordic and Cerkez Case No IT-95-14/2-AR (21 July 2000, Appeals Chamber) "Decision on Appeal Regarding Statement of a Deceased Witness"; Prosecutor v Aleksovski, above n 75.

240 Prosecutor v Brdjanin, above n 35, para 42.

241 See Prosecutor v Brdjanin, above n 35, para 42 (the Trial Chamber stated that the weight to be accorded to Randal's article "will depend to a great extent on evidence proving the level of [the interpreter's] proficiency in Serbo-Croatian at the time the interview took place."). 
deliver to any future permanent international criminal tribunal."242 Certainly, decisions of the two tribunals are not binding on the recently established International Criminal Court (ICC), but interpretations of their governing rules and statutes will be persuasive authority due to their similarities with those of the ICC. ${ }^{243}$

Although there are similarities, there are key differences that will impact considerably on the recognition of a qualified privilege for journalists on terms akin to the Appeals Chamber test. The first is that the ICC will apparently have less scope to develop rules 'ad hoc' as occurs in the ICTY and ICTR. ${ }^{244}$ Instead, amendments to the Rules will only take effect if there is a two-thirds majority of the Assembly of State Parties. ${ }^{245}$

An important difference is the provision in the Rules for privileges for certain types of information that is clearly influenced by Wigmore's four criteria. It is possible for "communications made in the context of a class of professional or other confidential relationships" to be regarded as privileged if the following conditions are met: ${ }^{246}$

(a) Communications occurring within that class of relationship are made in the course of a confidential relationship producing a reasonable expectation of privacy and non-disclosure;

(b) Confidentiality is essential to the nature and type of relationship between the person and the confidant; and

(c) Recognition of the privilege would further the objectives of the Statute and the Rules.

Although the journalist-source relationship is not mentioned specifically in the provision, ${ }^{247}$ the categories are not closed. ${ }^{248}$ Thus there is no gap in the Rules that would necessitate the use of a test

242 Dixon, above n 46, 102. The International Criminal Court was formed as a result of the coming into force of the Rome Statute of the International Criminal Court (July 17 1998) 37 ILM 999 ["Rome Statute"]. The Rules of Procedure and Evidence of the International Criminal Court were adopted by the Assembly of State Parties on 10 September 2002. See Doc ICC-ASP/1/3, available at <http://www.icccpi.int/library/basicdocuments/rules(e).pdf> ["ICC Rules of Procedure and Evidence"].

243 Stapleton, above n 63, 570. In drafting the Rome Statute of the International Criminal Court, the International Law Commission was clearly influenced by the work of the ICTY. See Scott T Johnson "On the Road to Disaster: The Rights of the Accused and the International Criminal Tribunal for the Former Yugoslavia" (1998) 10 Intl Legal Persp 111, 154. The ICC Rules of Procedure and Evidence contain much more detail than the ICTY Rules, with a total of 225 Rules compared to the ICTY's 127.

244 Indeed, The ICC Rules of Procedure and Evidence contain much more detail than the ICTY Rules, with a total of 225 Rules compared to the ICTY's 127.

245 Rome Statute, above n 242, Article 51. The judges are able to submit recommendations to the Parties, and can also pass temporary provisions, which can then be made permanent at the next Assembly.

246 ICC Rules of Procedure and Evidence, above n 242, Rule 73(2).

247 Rule 73(3) states that the Court will have "particular regard to recognising as privileged those communications made in the context of the professional relationship between a person and his or her 
similar to that of the Appeals Chamber, even if such ad hoc development was possible. The fact that there is no reference to non-confidential information may require discussion by the judges and the Assembly of the Parties in light of the findings in Randal's case, but the judges could not read this into the Rule due to its clear wording.

Certainly the first step for the Court would be to explicitly recognise that international human rights law and general principles of law confirm the importance of freedom of expression, ${ }^{249}$ and that a privilege for journalists fulfils the third criteria of the ICC test in that it is conducive to achieving the objectives of international justice. Such an interpretation of the Rule is particularly justified in light of the Rome Statute's applicable law provision, which clearly states that "[t]he application and interpretation of law pursuant to this article must be consistent with internationally recognized human rights." 250

The decision of the ICTY to grant a broad privilege to ICRC workers had a strong influence on the formulation of a specific rule for the application of this in the ICC. Rule 73(4) provides: ${ }^{251}$

The Court shall regard as privileged, and consequently not subject to disclosure, including by way of testimony of any present or past official or employee of the International Committee of the Red Cross (ICRC), any information, documents or other evidence which it came into the possession of in the course, or as a consequence, of the performance by ICRC of its functions under the Statutes of the International Red Cross and Red Crescent Movement.

The Rule goes on to set out the conditions that give rise to the need for consultations between the Court and the ICRC, which require the Court to determine whether "ICRC information, documents or other evidence are of great importance for a particular case." 252 In deciding to take this course, the Court will also have regard to "the circumstances of the case, the relevance of the evidence

medical doctor, psychiatrist, psychologist or counsellor, in particular those related to or involving victims, or between a person and a member of a religious clergy."

248 See DeFrancia, above n 180, 1435.

249 That these sources of law are highly relevant to interpreting the governing documents of the ICC is recognised in the Rome Statute's "Applicable Law" provision. Article 21(1) states that the Court shall apply: "(a) In the first place, this Statute, Elements of Crimes and its Rules of Procedure and Evidence; (b) In the second place, where appropriate, applicable treaties and the principles and rules of international law, including the established principles of the international law of armed conflict; (c) Failing that, general principles of law derived by the Court from national laws of legal systems of the world including, as appropriate, the national laws of States that would normally exercise jurisdiction over the crime, provided that those principles are not inconsistent with this Statute and with international law and internationally recognized norms and standards."

250 Rome Statute, above n 242, art 21(3).

251 ICC Rules of Procedure and Evidence, above n 242, Rule 73(4).

252 ICC Rules of Procedure and Evidence, above n 242, Rule 73(6). 
sought, whether the evidence could be obtained from a source other than ICRC, the interests of justice and of victims, and the performance of the Court's and ICRC's functions."253

In light of this provision, the Appeals Chamber test in Randal's case should be given considerable emphasis in establishing a similarly clear and principled privilege for war correspondents in the Rules of the ICC.

\section{CONCLUSION}

The Appeals Chamber decision in Randal's case is part of the development of a comprehensive procedural framework that "promises to spawn an entirely new international system of great importance." 254 The formulation of procedural rules will face the scrutiny of the international community. They must therefore be clear and principled, and meet the expectation that the international criminal justice system will respect fundamental human rights. The realities of the system are, however, different from any others in existence at either the domestic or the international level. The procedural framework that results will therefore be unique. At the same time, specific rules must be based to a large degree on principles that have developed over time in response to issues similar to those faced by the international tribunals. The Appeals Chamber's framing of the test to overcome the journalistic privilege is certainly grounded in the underlying rationale for similar privileges in other jurisdictions, and even reflects more specific principles evident in their approaches.

It is a feature of the work of the international tribunals that certain interests will inevitably come into conflict with each other. In particular, the desire of the prosecutor to secure convictions, the need for the accused to be able to present a defence, a court's interest in both of these factors in order to maintain its legitimacy, and the rights of other parties who are affected in the process. In general, therefore, the interests of the international criminal justice system are best served by achieving a fair balance that takes into account its broader purpose of furthering the establishment of peace.

In this context, the Appeals Chamber test for overcoming the evidentiary privilege of war correspondents protects the need, indeed the right, of the international community to receive information about activities that occur during conflicts, while ensuring that the important factfinding function of the tribunals is not overly hindered. Furthermore, neither the rights of the accused nor of war correspondents are derogated from in a way that is contrary to international human rights standards. The tribunals should be concerned, however, with ensuring that the rights of the accused are taken into account at all stages of the proceedings, particularly in terms of the weight given to any evidence that has not been subject to cross-examination.

253 ICC Rules of Procedure and Evidence, above n 242, Rule 73(6).

254 Dixon, above n 46, 102. 
The answers to the questions posed at the beginning of this paper are therefore as follows:

(1) The recognition of the privilege was in accordance with the authority to establish procedural rules provided by the Statute and by Rule 89(B) of the Rules of Procedure and Evidence;

(2) The Appeals Chamber acted consistently with the 'spirit' of its constituent documents and with general principles of law as required by that Rule. Apart from these sources, human rights standards are applicable to the Tribunals, and the journalists' privilege respects these and the conflict between them;

(3) More generally, there was a 'fair determination' of the issues raised by Randal's case, which in turn serves the broader needs of the international criminal justice system, particularly as the result is clear, principled, and justified in light of the applicable sources of law.

In terms of the practice of taking into account the special circumstances of the tribunals in formulating rules, this would seem a realistic and acceptable approach in most situations, provided the result is generally consistent with the above considerations. The reasoning and decision of the Appeals Chamber in Randal's case, however, is not only applicable in the particular context of the ICTY, but also to the international criminal justice system as a whole. The newly established International Criminal Court should therefore engage in a similar discussion regarding a journalistic privilege.

\section{POSTSCRIPT}

On 1 September 2004 the ICTY Trial Chamber found Radoslav Brdjanin guilty of persecutions; wilful killing; torture; wanton destruction of cities, towns or villages, or devastation not justified by military necessity; and destruction or wilful damage done to institutions dedicated to religion. ${ }^{255} \mathrm{He}$ was found not guilty of genocide.

Brdjanin was sentenced to 32 years imprisonment.

In total, 2736 and 314 exhibits were tendered in evidence by the Prosecution and by the Defence respectively. The Trial Chamber considered that Brdjanin's public speeches and use of the (primarily Serb-controlled) media to make public statements were part of an intentional propaganda campaign that created hatred and fear between the different ethnic groups, and that encouraged the execution of certain crimes. ${ }^{256}$ This contributed to the finding that he was criminally liable.

255 Prosecutor v Radoslav Brdjanin Case No IT-99-36-T (1 September 2004, Trial Chamber II) “Judgement”, para 1152.

256 Prosecutor v Radoslav Brdjanin, above n 1, paras 323 to 332. 
Indeed, it was stated that "among the leaders at the regional level, he was the one who appeared in the media most often."257 The evidence included televised or radio interviews and statements, excerpts from newspaper articles, and evidence from witnesses who heard some of Brdjanin's speeches or broadcasts. A number of witnesses gave evidence that his public statements were the main reason for them leaving the area of Banja Luka.

Although Randal's article was not specifically referred to as being relied on in the judgment, a note about Randal's case was included in an appendix. This reiterated that the article was admitted into evidence "without prejudice to the weight to be ascribed to it by the Trial Chamber in reaching its judgment."258 In general, however, the judgement appears to demonstrate that greater reliance was placed on evidence that was actually taped or televised, and on the accused's own published press releases, as being indicative of his state of mind. ${ }^{259}$

257 Prosecutor v Radoslav Brdjanin, above n 1, para 324.

258 Prosecutor v Radoslav Brdjanin, above n 1, Annex B para 1198.

259 See Prosecutor v Radoslav Brdjanin, above n 1, footnotes 847 to 868. 
